\title{
The evaluation of 1-tetralone and 4-chromanone derivatives as inhibitors of monoamine oxidase
}

\author{
Stephanus J. Cloete ${ }^{1} \cdot$ Clarina I. N'Da $^{1} \cdot$ Lesetja J. Legoabe $^{1} \cdot$ Anél Petzer $^{1,2} \cdot$ Jacobus P. Petzer $^{1,2}(\mathbb{O}$
}

Received: 27 May 2020 / Accepted: 11 September 2020 / Published online: 24 September 2020

(c) Springer Nature Switzerland AG 2020

\begin{abstract}
Monoamine oxidase (MAO) is of much clinical relevance, and inhibitors of this enzyme are used in the treatment for neuropsychiatric and neurodegenerative disorders such as depression and Parkinson's disease. The present study synthesises and evaluates the MAO inhibition properties of a series of 33 1-tetralone and 4-chromanone derivatives in an attempt to discover high-potency compounds and to expand on the structure-activity relationships of MAO inhibition by these classes. Among these series, eight submicromolar MAO-A inhibitors and 28 submicromolar MAO-B inhibitors are reported, with all compounds acting as specific inhibitors of the MAO-B isoform. The most potent inhibitor was a 1-tetralone derivative (1h) with $\mathrm{IC}_{50}$ values of 0.036 and $0.0011 \mu \mathrm{M}$ for MAO-A and MAO-B, respectively. Interestingly, with the reduction of 1-tetralones to the corresponding alcohols, a decrease in MAO inhibition potency is observed. Among these 1-tetralol derivatives, $\mathbf{1 p}\left(\mathrm{IC}_{50}=0.785 \mu \mathrm{M}\right)$ and $\mathbf{1 0}\left(\mathrm{IC}_{50}=0.0075 \mu \mathrm{M}\right)$ were identified as particularly potent inhibitors of MAO-A and MAO-B, respectively. Potent compounds such as those reported here may act as leads for the future development of MAO-B specific inhibitors.
\end{abstract}

\section{Graphic abstract}

The present study describes the MAO inhibitory activities of a series of 1-tetralone and 4-chromanone derivatives. Numerous high-potency MAO-B specific inhibitors were identified.<smiles>OC1CCCc2cc(OCc3ccc(Cl)cc3)ccc21</smiles>

$\mathrm{IC}_{50}(\mathrm{MAO}-\mathrm{A})=1.086 \mu \mathrm{M}$

$\mathrm{IC}_{50}(\mathrm{MAO}-\mathrm{B})=0.0075 \mu \mathrm{M}$
Potent MAO-B inhibition

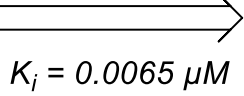

$K_{i}=0.0065 \mu \mathrm{M}$

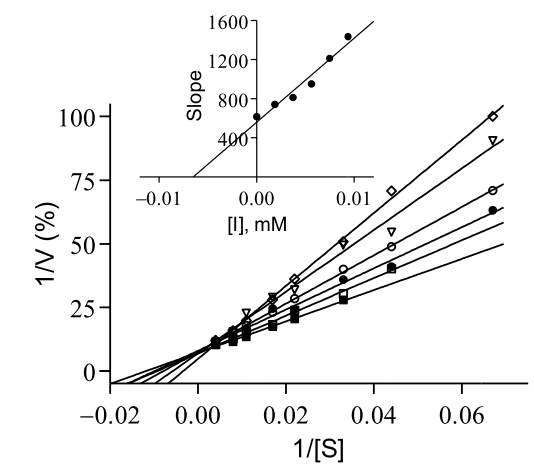

Keywords 1 -Tetralone $\cdot 4$-Chromanone $\cdot$ Monoamine oxidase $\cdot$ Inhibition $\cdot$ Parkinson's disease

\section{Introduction}

Electronic supplementary material The online version of this article (https://doi.org/10.1007/s11030-020-10143-w) contains supplementary material, which is available to authorised users.

Jacobus P. Petzer

jacques.petzer@nwu.ac.za

Extended author information available on the last page of the article
The monoamine oxidase (MAO) enzymes are of much clinical interest since they metabolise neurotransmitter and dietary amines in the peripheral and central tissues [1]. Amine substrates undergo MAO-catalysed deamination to yield an aldehyde, ammonia (or a substituted amine) and hydrogen 
peroxide as products. Two MAO isoforms which are products of distinct genes are expressed in mammalian tissues, MAO-A and MAO-B. These two isoforms are approximately $70 \%$ similar on the amino acid sequence level $[2,3]$. Considerable overlap in substrate specificities occurs between MAO-A and MAO-B, and dopamine, adrenaline, noradrenaline and tyramine are substrates for both isoforms [4]. In contrast, serotonin is a MAO-A specific substrate, while the arylalkylamines, benzylamine and 2-phenylethylamine are specific substrates for MAO-B.

Since inhibitors of MAO-A reduce the central catabolism of serotonin (and to a lesser extent noradrenaline), these compounds have been used as antidepressant and anxiolytic agents for many decades [5]. MAO-B inhibitors, in turn, block the central catabolism of dopamine and are established treatment for symptomatic Parkinson's disease [6]. In Parkinson's disease, MAO-B inhibitors are combined with levodopa, the metabolic precursor of dopamine, for the treatment for motor fluctuations. MAO inhibitors may be of further therapeutic relevance by reducing the formation of hydrogen peroxide that is produced by the MAO catalytic cycle [7]. In this regard, MAO inhibitors may protect susceptible neurons in the brain from oxidative damage mediated by reactive oxygen species (produced from hydrogen peroxide) and thus act as potential neuroprotective agents in Parkinson's disease [1]. Similarly, MAO-A is a source of hydrogen peroxide in the heart, and inhibitors may thus potentially protect against the development and progression of heart disease by reducing hydrogen peroxide production and intracellular levels of reactive oxygen species $[8,9]$. Interestingly, MAO inhibitors may have roles in the treatment for other disease states, most notably prostate cancer, cardiovascular disease and inflammatory diseases [10-12]. Furthermore, MAO inhibitors such as phenelzine and tranylcypromine have been shown to lead to disease remission in patients suffering from Crohn's disease or rheumatoid arthritis [13, 14].

Based on these considerations, much interest in the discovery and development of MAO inhibitors exists in academia and industry [12]. Based on reports that 1-tetralone derivatives act as MAO inhibitors, this study synthesised a series of 1-tetralone derivatives in an effort to expand on the structure-activity relationships (SARs) of MAO inhibition by this class of compounds $[15,16]$. In particular, the effect on MAO inhibition of the reduction of the 1-tetralone carbonyl group to the corresponding alcohol was determined. For this purpose, this study synthesises the derivatives 1a-p shown in Table 1. The chemical modifications that were made to 1-tetralone included substitution on C5, C6 and C7 and reduction of the carbonyl to the corresponding alcohol. The substituents considered were the benzyloxy and 2-phenoxyethoxy moieties. Both these substituents have been shown to enhance the MAO inhibition potencies of caffeine derivatives, while the benzyloxy side chain has also been shown to yield good MAO inhibition when substituted on C6 and C7 of 1-tetralone [15-18].

4-Chromanone compounds are the corresponding pyranone analogues of 1-tetralone and with appropriate substitution, may be expected to act as suitable scaffolds for the design of MAO inhibitors. In accordance with this, a recent study shows that a series of 4-chromanones acts as potent MAO inhibitors [19]. This study expands on the SARs of MAO inhibition by 4-chromanone compounds by investigating a series substituted on $\mathrm{C} 7$ with a variety of substituents $(\mathbf{2 a}-\mathbf{q})$ (Table 2). In this respect, benzyloxy, 2-phenylethoxy, 3-phenylpropoxy and 2-phenoxyethoxy substitution of 4-chromanone was considered. In particular, substitution with halogens $(\mathrm{Cl}, \mathrm{Br}$ and $\mathrm{F})$ on the phenyl rings of these moieties was investigated since such substitution has been shown to be beneficial for MAO-B inhibition [19]. The C7 position was selected since substitution of 1-tetralones on C7 yields significantly better MAO inhibition than substitution on C6 [15, 16]. Examples of 1-tetralone (3-4) and 4-chromanone (5-6) compounds that have been reported to be potent MAO inhibitors are given in Fig. 1.

\section{Results and discussion}

\section{Chemistry}

In the first step of the synthesis of the 1-tetralone derivatives, the key starting materials, namely 5-, 6- and 7-hydroxy1-tetralone $(\mathbf{8 a}-\mathbf{c})$, were synthesised from the corresponding methoxy-1-tetralone derivatives $(\mathbf{7 a}-\mathbf{c})$ by reaction with aluminium chloride $\left(\mathrm{AlCl}_{3}\right)$ (Fig. 2) $[15,16]$. In the subsequent step, the hydroxy derivatives were alkylated with a benzyl bromide or 2-phenoxyethyl bromide to yield the substituted 1-tetralone derivatives $\mathbf{1 a}-\mathbf{h}[15,16]$. Reduction with sodium borohydride $\left(\mathrm{NaBH}_{4}\right)$ yielded the alcohol derivatives 1i-p. The reduction of achiral carbonyl compounds with sodium borohydride yields the racemic alcohols [20].

The 4-chromanone derivatives $(\mathbf{2} \mathbf{a}-\mathbf{q})$ were synthesised by alkylation of 7-hydroxy-4-chromanone (12) with an appropriately substituted arylalkyl bromide in the presence of potassium carbonate (Fig. 3). 7-Hydroxy-4-chromanone (12), in turn, was obtained from reaction of resorcinol (9) and 3-chloropropionic acid (10) in the presence of trifluoromethanesulfonic acid to give 2',4'-dihydroxy-3-chloropropiophenone (11), which was further cyclised in $\mathrm{NaOH}$ to give 12 [21].

\section{MAO inhibition studies}

The series of tetralone and chromanone derivatives were investigated as potential inhibitors of recombinant human MAO-A and MAO-B [22]. For this purpose, kynuramine 
Table $1 \mathrm{IC}_{50}$ values for the inhibition of recombinant human MAO-A and MAO-B by compounds $\mathbf{1 a}-\mathbf{p}$

\begin{tabular}{|c|c|c|c|c|c|}
\hline & \multirow[t]{2}{*}{$\mathrm{R}$} & \multirow[t]{2}{*}{ Position } & \multicolumn{2}{|l|}{$\mathrm{IC}_{50}(\mu \mathrm{M})^{\mathrm{a}}$} & \multirow[t]{2}{*}{$\mathrm{SI}^{\mathrm{b}}$} \\
\hline & & & MAO-A & MAO-B & \\
\hline $1 \mathbf{a}$ & $\mathrm{C}_{6} \mathrm{H}_{5} \mathrm{CH}_{2} \mathrm{O}$ & 5 & $53.9 \pm 7.02$ & $3.62 \pm 0.34$ & 15 \\
\hline $1 b$ & $\mathrm{C}_{6} \mathrm{H}_{5} \mathrm{CH}_{2} \mathrm{O}$ & 6 & $\begin{array}{l}1.39 \pm 0.30 \\
\left(0.792^{\mathrm{d}}\right)\end{array}$ & $\begin{array}{l}0.025 \pm 0.0029 \\
\left(0.063^{\mathrm{d}}\right)\end{array}$ & 56 \\
\hline $1 c$ & $\mathrm{C}_{6} \mathrm{H}_{5} \mathrm{CH}_{2} \mathrm{O}$ & 7 & $\begin{array}{l}0.623 \pm 0.021 \\
\left(0.443^{\mathrm{d}}\right)\end{array}$ & $\begin{array}{l}0.0024 \pm 0.0004 \\
\left(0.0072^{\mathrm{d}}\right)\end{array}$ & 260 \\
\hline 1d & $\mathrm{C}_{6} \mathrm{H}_{5} \mathrm{OCH}_{2} \mathrm{CH}_{2} \mathrm{O}$ & 5 & $\mathrm{NI}^{\mathrm{c}}$ & $3.26 \pm 1.86$ & $>31$ \\
\hline $1 e$ & $\mathrm{C}_{6} \mathrm{H}_{5} \mathrm{OCH}_{2} \mathrm{CH}_{2} \mathrm{O}$ & 6 & $2.58 \pm 0.30$ & $0.033 \pm 0.0053$ & 78 \\
\hline 1f & $\mathrm{C}_{6} \mathrm{H}_{5} \mathrm{OCH}_{2} \mathrm{CH}_{2} \mathrm{O}$ & 7 & $1.91 \pm 0.37$ & $0.0012 \pm 0.0003$ & 1592 \\
\hline $1 \mathrm{~g}$ & $4-\mathrm{ClC}_{6} \mathrm{H}_{4} \mathrm{CH}_{2} \mathrm{O}$ & 6 & $\begin{array}{l}0.575 \pm 0.018 \\
\left(0.238^{\mathrm{d}}\right)\end{array}$ & $\begin{array}{l}0.0055 \pm 0.0006 \\
\left(0.007^{\mathrm{d}}\right)\end{array}$ & 105 \\
\hline 1h & $4-\mathrm{ClC}_{6} \mathrm{H}_{4} \mathrm{CH}_{2} \mathrm{O}$ & 7 & $\begin{array}{l}0.036 \pm 0.0059 \\
\left(0.033^{\mathrm{d}}\right)\end{array}$ & $\begin{array}{l}0.0011 \pm 0.0002 \\
\left(0.0041^{\mathrm{d}}\right)\end{array}$ & 33 \\
\hline $\mathbf{1 i}$ & $\mathrm{C}_{6} \mathrm{H}_{5} \mathrm{CH}_{2} \mathrm{O}$ & 5 & $9.27 \pm 0.83$ & $5.05 \pm 0.42$ & 1.8 \\
\hline $\mathbf{1 j}$ & $\mathrm{C}_{6} \mathrm{H}_{5} \mathrm{CH}_{2} \mathrm{O}$ & 6 & $35.5 \pm 5.60$ & $0.079 \pm 0.012$ & 449 \\
\hline $1 \mathrm{k}$ & $\mathrm{C}_{6} \mathrm{H}_{5} \mathrm{CH}_{2} \mathrm{O}$ & 7 & $34.6 \pm 3.80$ & $0.249 \pm 0.061$ & 139 \\
\hline 11 & $\mathrm{C}_{6} \mathrm{H}_{5} \mathrm{OCH}_{2} \mathrm{CH}_{2} \mathrm{O}$ & 5 & $\mathrm{NI}^{\mathrm{c}}$ & $1.66 \pm 0.14$ & $>60$ \\
\hline $1 \mathrm{~m}$ & $\mathrm{C}_{6} \mathrm{H}_{5} \mathrm{OCH}_{2} \mathrm{CH}_{2} \mathrm{O}$ & 6 & $\mathrm{NI}^{\mathrm{c}}$ & $0.068 \pm 0.0034$ & $>1471$ \\
\hline 1n & $\mathrm{C}_{6} \mathrm{H}_{5} \mathrm{OCH}_{2} \mathrm{CH}_{2} \mathrm{O}$ & 7 & $\mathrm{NI}^{\mathrm{c}}$ & $0.189 \pm 0.013$ & $>529$ \\
\hline 10 & $4-\mathrm{ClC}_{6} \mathrm{H}_{4} \mathrm{CH}_{2} \mathrm{O}$ & 6 & $1.086 \pm 0.12$ & $0.0075 \pm 0.0011$ & 145 \\
\hline $1 p$ & $4-\mathrm{ClC}_{6} \mathrm{H}_{4} \mathrm{CH}_{2} \mathrm{O}$ & 7 & $0.785 \pm 0.047$ & $0.039 \pm 0.013$ & 20 \\
\hline
\end{tabular}

${ }^{a}$ All values are expressed as the mean $\pm \mathrm{SD}$ of triplicate determinations

${ }^{\mathrm{b}}$ Selectivity index $(\mathrm{SI})=\mathrm{IC}_{50}(\mathrm{MAO}-\mathrm{A}) / \mathrm{IC}_{50}(\mathrm{MAO}-\mathrm{B})$

${ }^{\mathrm{c}}$ No inhibition observed at maximum tested concentration of $100 \mu \mathrm{M}$

${ }^{\mathrm{d}}$ Values from references $[15,16]$

was used as enzyme-substrate for both MAO isoforms. Kynuramine is oxidised by MAO to yield 4-hydroxyquinoline, which may be accurately measured and quantitated by fluorescence spectrophotometry, as it fluoresces in alkaline media $[23,24]$. This procedure represents a swift and dependable assay for the evaluation of MAO activity. Typical enzyme reactions contained kynuramine $(50 \mu \mathrm{M})$, the test inhibitor $(0.0003-100 \mu \mathrm{M})$ and DMSO as co-solvent. The reactions were initiated with the addition of MAO, incubated for $20 \mathrm{~min}$ and terminated with the addition of sodium hydroxide. At endpoint, 4-hydroxyquinoline concentrations in the incubations were measured and enzyme catalytic rates were calculated. Sigmoidal curves of enzyme catalytic rate versus the logarithm of inhibitor concentration were constructed from which the $\mathrm{IC}_{50}$ values were determined (Fig. 4). The $\mathrm{IC}_{50}$ values for the inhibition of MAO are presented in Tables 1 and 2.

\section{MAO inhibition by the tetralone derivatives}

It is clear that both the 1-tetralone (1a-h) and alcohol $(\mathbf{1} \mathbf{i}-\mathbf{p})$ derivatives are selective inhibitors of MAO-B over the MAO-A isoform (Table 1). In this respect, the SI values were $>1.8$, indicating selectivity for MAO-B in all cases. Among the compounds evaluated, $\mathbf{1 d}$ and $\mathbf{1 l}-\mathbf{n}$ are particularly selective and do not display inhibition of MAO-A at a maximal tested concentration of $100 \mu \mathrm{M}$. Although the 1-tetralone and alcohol derivatives are MAO-B selective, some compounds were found to be good-potency MAO-A inhibitors. Compound $\mathbf{1 h}$, in particular, is a high-potency MAO-A inhibitor with an $\mathrm{IC}_{50}$ value of $0.036 \mu \mathrm{M}$. This is 108-fold more potent than the reference MAO-A inhibitor, toloxatone $\left(\mathrm{IC}_{50}=3.92 \mu \mathrm{M}\right)$, which was evaluated under identical experimental conditions [25]. This study also identifies three other compounds with submicromolar MAO-A 
Table $2 \mathrm{IC}_{50}$ values for the inhibition of recombinant human MAO-A and MAO-B by compounds $\mathbf{2 a}-\mathbf{q}$ and $\mathbf{1 2}$<smiles>[R]c1ccc2c(c1)OCCC2=O</smiles>

\begin{tabular}{|c|c|c|c|c|}
\hline & $\mathrm{R}$ & $\mathrm{IC}_{50}(\mu \mathrm{M})^{\mathrm{a}}$ & & $\mathrm{SI}^{\mathrm{b}}$ \\
\hline & & MAO-A & MAO-B & \\
\hline $2 \mathbf{a}$ & $\mathrm{C}_{6} \mathrm{H}_{5} \mathrm{CH}_{2} \mathrm{O}$ & $\begin{array}{l}\mathrm{NI}^{\mathrm{c}} \\
\left(18 \%{ }^{\mathrm{e}}\right)\end{array}$ & $\begin{array}{l}0.015 \pm 0.003 \\
\left(0.057^{\mathrm{d}}\right)\end{array}$ & $>6666$ \\
\hline $2 b$ & $\mathrm{C}_{6} \mathrm{H}_{5}\left(\mathrm{CH}_{2}\right)_{2} \mathrm{O}$ & $2.49 \pm 0.965$ & $0.018 \pm 0.003$ & 138 \\
\hline $2 c$ & $\mathrm{C}_{6} \mathrm{H}_{5}\left(\mathrm{CH}_{2}\right)_{3} \mathrm{O}$ & $6.40 \pm 0.581$ & $0.019 \pm 0.006$ & 337 \\
\hline 2d & $\mathrm{C}_{6} \mathrm{H}_{11}\left(\mathrm{CH}_{2}\right)_{2} \mathrm{O}$ & $7.33 \pm 0.222$ & $0.015 \pm 0.003$ & 489 \\
\hline $2 \mathrm{e}$ & $4-\mathrm{BrC}_{6} \mathrm{H}_{4} \mathrm{CH}_{2} \mathrm{O}$ & $\begin{array}{l}0.332 \pm 0.026 \\
(19 \%)\end{array}$ & $\begin{array}{l}0.0059 \pm 0.002 \\
\left(0.022^{\mathrm{d}}\right)\end{array}$ & 56 \\
\hline $2 f$ & 4- $\mathrm{ClC}_{6} \mathrm{H}_{4} \mathrm{CH}_{2} \mathrm{O}$ & $\begin{array}{l}0.410 \pm 0.044 \\
\left(37 \%{ }^{\mathrm{e}}\right)\end{array}$ & $\begin{array}{l}0.004 \pm 0.0008 \\
\left(0.033^{\mathrm{d}}\right)\end{array}$ & 103 \\
\hline $2 \mathrm{~g}$ & 4- $\mathrm{CH}_{3} \mathrm{C}_{6} \mathrm{H}_{4} \mathrm{CH}_{2} \mathrm{O}$ & $\begin{array}{l}\mathrm{NI}^{\mathrm{c}} \\
\left(26 \%^{\mathrm{e}}\right)\end{array}$ & $\begin{array}{l}0.012 \pm 0.001 \\
\left(0.091^{\mathrm{d}}\right)\end{array}$ & $>8333$ \\
\hline $2 h$ & $4-\mathrm{FC}_{6} \mathrm{H}_{4} \mathrm{CH}_{2} \mathrm{O}$ & $\begin{array}{l}1.04 \pm 0.107 \\
\left(43 \%^{\mathrm{e}}\right)\end{array}$ & $\begin{array}{l}0.0067 \pm 0.0001 \\
\left(0.0086^{\mathrm{d}}\right)\end{array}$ & 155 \\
\hline $2 \mathbf{i}$ & $4-\mathrm{CF}_{3} \mathrm{C}_{6} \mathrm{H}_{4} \mathrm{CH}_{2} \mathrm{O}$ & $3.33 \pm 0.101$ & $0.0038 \pm 0.0001$ & 876 \\
\hline $2 \mathbf{j}$ & $\mathrm{C}_{6} \mathrm{H}_{5} \mathrm{O}\left(\mathrm{CH}_{2}\right)_{2} \mathrm{O}$ & $\mathrm{NI}^{\mathrm{c}}$ & $0.014 \pm 0.003$ & $>7142$ \\
\hline $2 \mathbf{k}$ & $4-\mathrm{ClC}_{6} \mathrm{H}_{4} \mathrm{O}\left(\mathrm{CH}_{2}\right)_{2} \mathrm{O}$ & $\mathrm{NI}^{\mathrm{c}}$ & $0.008 \pm 0.002$ & $>12,500$ \\
\hline 21 & $4-\mathrm{BrC}_{6} \mathrm{H}_{4} \mathrm{O}\left(\mathrm{CH}_{2}\right)_{2} \mathrm{O}$ & $\mathrm{NI}^{\mathrm{c}}$ & $0.030 \pm 0.002$ & $>3333$ \\
\hline $2 \mathrm{~m}$ & $4-\mathrm{CH}_{3} \mathrm{OC}_{6} \mathrm{H}_{4}\left(\mathrm{CH}_{2}\right)_{2} \mathrm{O}$ & $13.6 \pm 0.261$ & $1.06 \pm 0.078$ & 13 \\
\hline $2 n$ & $4-\mathrm{ClC}_{6} \mathrm{H}_{4}\left(\mathrm{CH}_{2}\right)_{2} \mathrm{O}$ & $0.286 \pm 0.036$ & $0.043 \pm 0.00002$ & 6.7 \\
\hline 20 & $4-\mathrm{FC}_{6} \mathrm{H}_{4} \mathrm{O}\left(\mathrm{CH}_{2}\right)_{2} \mathrm{O}$ & $5.74 \pm 1.15$ & $0.010 \pm 0.002$ & 574 \\
\hline $2 p$ & 4- $\mathrm{CH}_{3} \mathrm{C}_{6} \mathrm{H}_{4}\left(\mathrm{CH}_{2}\right)_{2} \mathrm{O}$ & $9.66 \pm 0.345$ & $0.356 \pm 0.017$ & 27 \\
\hline $2 q$ & Isoamyl-O & $0.844 \pm 0.088$ & $0.006 \pm 0.001$ & 141 \\
\hline 12 & $\mathrm{OH}$ & $\mathrm{NI}^{\mathrm{c}}$ & $34.2 \pm 3.21$ & $>2.9$ \\
\hline
\end{tabular}

${ }^{\mathrm{a}-\mathrm{c}}$ See Table 1 for footnotes

${ }^{\mathrm{d}}$ Values from Ref. [19]

${ }^{\mathrm{e}}$ Percentage (\%) inhibition at $100 \mu \mathrm{M}$ [19] inhibition potencies, compounds $1 \mathrm{c}\left(\mathrm{IC}_{50}=0.623 \mu \mathrm{M}\right), \mathbf{1 g}$ $\left(\mathrm{IC}_{50}=0.575 \mu \mathrm{M}\right)$ and $1 \mathbf{p}\left(\mathrm{IC}_{50}=0.785 \mu \mathrm{M}\right)$. As mentioned, the 1-tetralone and alcohol derivatives are MAO-B selective inhibitors. This study discovers several high-potency MAO-B inhibitors. Among the 16 compounds evaluated, ten compounds display $\mathrm{IC}_{50}<0.1 \mu \mathrm{M}$, while five compounds display $\mathrm{IC}_{50}<0.01 \mu \mathrm{M}$. The most potent MAO-B inhibitors are compounds $\mathbf{1 f}$ and $\mathbf{1 h}$ with $\mathrm{IC}_{50}$ values of 0.0012 and $0.0011 \mu \mathrm{M}$, respectively. These compounds are 75 -fold more potent than the reference MAO-B inhibitor, lazabemide $\left(\mathrm{IC}_{50}=0.091 \mu \mathrm{M}\right)$, which was evaluated under identical experimental conditions [25].

From the MAO-A inhibition data, the following structure-activity relationships (SARs) may be derived. Among the 1-tetralone derivatives, the position of the substituent on the 1-tetralone moiety has a pronounced effect on the inhibition potency with substitution on $\mathrm{C} 7$ yielding more potent inhibition than substitution on C6 (e.g. 1c vs. 1b).
Substitution on C6 in turn leads to more potent inhibition than substitution on C5 (e.g. 1b vs. 1a). This trend is observed for all the 1-tetralone derivatives evaluated. For the alcohol derivatives, a clear trend with regard to the position of the substituent was not observed. It is, however, noteworthy that the $\mathrm{C} 7$-substituted derivative $\mathbf{1 p}$ is more potent than the corresponding C6-substituted derivative 1o. It is also noteworthy that the derivatives containing chlorine are more potent MAO-A inhibitors compared to the corresponding unsubstituted homologues (e.g. 1h vs. 1c). This trend is observed for all compounds evaluated, including the alcohol derivatives (e.g. 1p vs. 1k).

From the MAO-B inhibition data, the following SARs may be derived. As for MAO-A, substitution on $\mathrm{C} 7$ yields more potent inhibition than substitution on $\mathrm{C} 6$ (e.g. 1c vs. 1b). Substitution on C6 in turn leads to more potent inhibition than substitution on C5 (e.g. 1b vs. 1a). This trend is observed for all the 1-tetralone derivatives evaluated. 
<smiles>O=C1CCCc2cc(OCc3ccccc3)ccc21</smiles>

3

$\mathrm{IC}_{50}(\mathrm{MAO}-\mathrm{A})=0.792 \mu \mathrm{M}$

$\mathrm{IC}_{50}(\mathrm{MAO}-\mathrm{B})=0.063 \mu \mathrm{M}$<smiles>O=C1CCOc2cc(OCc3ccc(F)cc3)ccc21</smiles>

$$
\mathrm{IC}_{50}(\mathrm{MAO}-\mathrm{A})>100 \mu \mathrm{M}
$$$$
\mathrm{IC}_{50}(\mathrm{MAO}-\mathrm{B})=0.0086 \mu \mathrm{M}
$$<smiles>O=C1CCCc2ccc(OCc3ccccc3)cc21</smiles>

$\mathrm{IC}_{50}(\mathrm{MAO}-\mathrm{A})=0.443 \mu \mathrm{M}$

$\mathrm{IC}_{50}(\mathrm{MAO}-\mathrm{B})=0.0072 \mu \mathrm{M}$

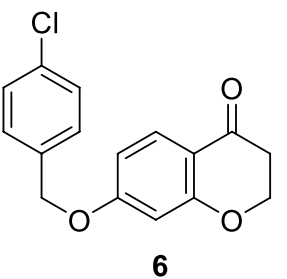

$\mathrm{IC}_{50}(\mathrm{MAO}-\mathrm{A})>100 \mu \mathrm{M}$

$\mathrm{IC}_{50}(\mathrm{MAO}-\mathrm{B})=0.033 \mu \mathrm{M}$
Fig. 1 1-Tetralone (3-4) and 4-chromanone (5-6) compounds that have been reported to act as MAO inhibitors $[15,16,19]$<smiles>COc1ccc2c(c1)C(=O)CCC2</smiles><smiles>[R20][14c]1ccc2c(c1)C(=O)CCC2</smiles>

Fig. 2 Reaction pathway for the synthesis of 1-tetralone derivatives (1a-h), and subsequent reduction to the alcohol derivatives $\mathbf{1 i}-\mathbf{p}$. Key: a $\mathrm{AlCl}_{3}$, toluene, reflux, $1-2 \mathrm{~h}$; b $\mathrm{RBr}, \mathrm{K}_{2} \mathrm{CO}_{3}$, acetone, reflux, $20 \mathrm{~h} ; \mathbf{c} \mathrm{NaBH}_{4}$, ethanol, reflux, $18 \mathrm{~h}$
For the alcohol derivatives, a clear trend with regard to the position of the substituent was not observed. Interestingly, among the alcohol derivatives, a C6-substituted derivative $10\left(\mathrm{IC}_{50}=0.0075 \mu \mathrm{M}\right)$ is the most potent MAO-B inhibitor. For MAO-B inhibition, the chlorine-containing compounds also are more potent inhibitors compared to the unsubstituted derivatives (e.g. 1g vs. 1b, and 10 vs. 1j). This trend is observed for both the 1-tetralone and alcohol derivatives. A further SAR is that among the 1-tetralone derivatives, the 2-phenoxyethoxy-substituted derivatives are weaker MAO-A and MAO-B inhibitors than the corresponding benzyloxy-substituted derivatives (e.g. 1d-f vs. 1a-c). The exception here is that $\mathbf{1 f}$ is a higher potency MAO-B inhibitor than 1c, while MAO-B inhibition by $\mathbf{1 a}$ and $\mathbf{1 d}$ is similar. Among the alcohol derivatives, this trend is also observed for MAO-A, but not for MAO-B inhibition (e.g. 1l-n vs. $\mathbf{1 i - k ) . ~ I t ~ i s ~ n o t e w o r t h y ~ t h a t ~ t h e ~ a l c o h o l ~ d e r i v a t i v e s ~ s u b s t i - ~}$ tuted with the 2-phenoxyethoxy are not MAO-A inhibitors with $\mathrm{IC}_{50}>100 \mu \mathrm{M}$. This group of compounds is thus highly selective for MAO-B with $\mathbf{1 m}$ representing a particularly potent MAO-B inhibitor.

Finally, it should be kept in mind that the 1-tetralol derivatives are the racemic mixtures of two enantiomers. Considering that two enantiomers may exhibit different inhibition potencies, the $\mathrm{IC}_{50}$ values given in Table 1 are the combination of the individual enantiomeric potencies. The higher potency enantiomer may thus exhibit a much higher degree of inhibition than that given in the results table. For this reason, clear SARs and trends are not as readily observed for the alcohol derivatives compared to the 1-tetralone derivatives. Considering this, it is not surprising that with the exception of 1a vs. 1i (MAO-A) and 1d vs. 11 (MAO-B), the 1 -tetralone derivatives are in all instances more potent $\mathrm{MAO}$ inhibitors than the corresponding alcohol derivatives. The enantiomers of a number of inhibitors exhibit different inhibition potencies towards the MAOs and include compounds such as (R)-deprenyl, rasagiline, safinamide and a variety of experimental compounds such as pyrazoline derivatives $[4,26,27]$.
Fig. 3 Reaction pathway for the synthesis of 4-chromanone derivatives (2a-q). Key: a $\mathrm{CF}_{3} \mathrm{SO}_{3} \mathrm{H}, 80^{\circ} \mathrm{C}, 1.5 \mathrm{~h} ; \mathbf{b}$ $2 \mathrm{~N} \mathrm{NaOH}, 0{ }^{\circ} \mathrm{C}, 4 \mathrm{~h}$; $\mathbf{c ~ R B r}$, $\mathrm{K}_{2} \mathrm{CO}_{3}$, acetone, reflux, $20 \mathrm{~h}$<smiles>Oc1cccc(O)c1</smiles><smiles>O=C(O)CCCl</smiles><smiles>CC(C)C</smiles><smiles>O=C(CCCl)c1ccc(O)cc1O</smiles>

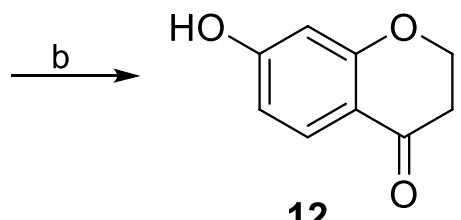<smiles>[R6]Oc1ccc2c(c1)OCCC2=O</smiles>

2a-q 


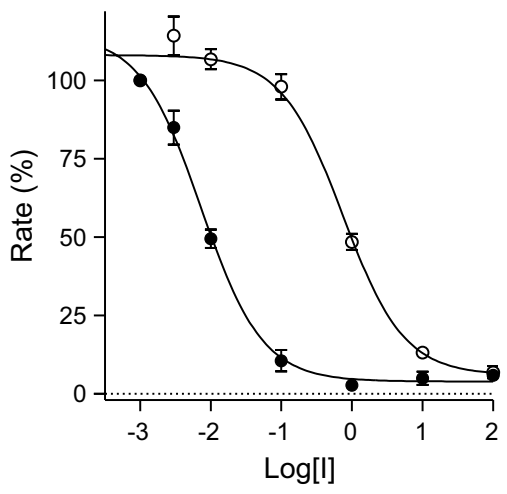

Fig. 4 Examples of sigmoidal plots obtained for the inhibition of MAO-A by $\mathbf{1 p}$ (open circles) and MAO-B by 10 (filled circles)

Literature reports the MAO inhibition potencies of a number of 1-tetralone derivatives that have been substituted on C6 and C7 with the benzyloxy side chain $[15,16]$. When considering these as well as the 1-tetralones of the current study, the following observations may be made: (1) In most instances, substitution on the benzyloxy ring with both halogens $(\mathrm{F}, \mathrm{Cl}, \mathrm{Br}, \mathrm{I})$ and alkyl groups $\left(\mathrm{CH}_{3}\right.$, $\mathrm{CN}, \mathrm{CF}_{3}$ ) enhances MAO-B inhibition compared to the unsubstituted derivative. A clear trend regarding preference for meta vs. para substitution is not apparent, with very similar inhibition potencies recorded for these two positions. (2) For MAO-A inhibition, substitution on the benzyloxy ring with both halogens $(\mathrm{F}, \mathrm{Cl}, \mathrm{Br})$ and alkyl groups $\left(\mathrm{CN}, \mathrm{CF}_{3}\right)$ also enhances potency compared to the unsubstituted derivative. The notable exception is a significant reduction in MAO-A inhibition potency observed for meta and para substitution with methyl and iodo groups (with benzyloxy ring on $\mathrm{C} 6$ ), and para $\mathrm{CF}_{3}$ substitution (with benzyloxy ring on $\mathrm{C} 7$ ). Again, no apparent trend exists regarding preference for meta vs. para substitution. (3) In general, benzyloxy substitution on $\mathrm{C} 7$ results in more potent MAO-A and MAO-B inhibition compared to substitution on $\mathrm{C} 6$, which in turn is more beneficial than substitution on C5. (4) While it would be speculative to identify a group and position (meta vs. para) that is most beneficial for MAO-B inhibition, bromo substitution consistently leads to compounds with $\mathrm{IC}_{50}<0.009 \mu \mathrm{M}$ for both positions. For MAO-A, substitution with the cyano group on the meta position has been particularly beneficial. (5) It is clear that benzyloxy substitution on both C6 and C7 is preferable for MAO-A inhibition compared to substitution with the 2-phenylethoxy, 3-phenylpropoxy and 2-phenoxyethoxy moieties. The only exception is 2-phenylethoxy substitution on C7. For MAO-B, 2-phenylethoxy and 3-phenylpropoxy substitution on C6 yields slightly better inhibition compared to benzyloxy substitution, while on $\mathrm{C} 7$, the benzyloxy moiety is preferred.
2-Phenoxyethoxy substitution on both $\mathrm{C} 6$ and $\mathrm{C} 7$ yields similar MAO-B inhibition potencies compared to benzyloxy substitution.

\section{MAO inhibition by chromanone derivatives}

Table 2 gives the $\mathrm{IC}_{50}$ values for the inhibition of human MAO-A and MAO-B by the 4-chromanone derivatives. The 4-chromanones are specific inhibitors of MAO-B with 15 compounds (of 17) displaying $\mathrm{IC}_{50}<0.1 \mu \mathrm{M}$. Only four compounds have $\mathrm{IC}_{50}<1 \mu \mathrm{M}$ for the inhibition of MAO-A, with the most potent compound (2n) exhibiting an $\mathrm{IC}_{50}$ of $0.286 \mu \mathrm{M}$. While clear SARs for the inhibition of MAO-B are not apparent, a variety of $\mathrm{C} 7$ substituents yield goodpotency inhibition, e.g. benzyloxy (2a, 2e-i), 2-phenylethoxy (2b, 2m, 2n, 2p), 3-phenylpropoxy (2c), 2-cyclohexylethoxy (2d), 2-phenoxyethoxy $(\mathbf{2} \mathbf{j}-\mathbf{l}, \mathbf{2 o})$ and isoamyloxy (2q). This demonstrates that C7-substituted 4-chromanones are a class of high-potency MAO-B specific inhibitors. The $\mathrm{C} 7$ substituent is a requirement for inhibition since 7-hydroxy-4-chromanone $\left(\mathbf{1 2}, \mathrm{IC}_{50}=34.2 \mu \mathrm{M}\right)$ is a weak MAO-B inhibitor. For the benzyloxy-substituted homologues (2a, 2e-i), the presence of a halogen (e.g. $2 \mathbf{e}, \mathbf{2 f}, \mathbf{2 h}$, 2i) leads to higher MAO-B inhibition potency compared to the unsubstituted homologue (2a) and the methyl-substituted compound (2g). This trend is not as apparent for the other substituents considered, although the methoxy- and methylsubstituted compounds are the weakest MAO-B inhibitors among the 2-phenylethoxy (e.g. 2m, 2p)-substituted 4-chromanones.

The MAO inhibition potencies of a number of 4-chromanone derivatives have also been reported, with most being substituted on C7 with the benzyloxy moiety [19]. When considering these 4-chromanone derivatives and those of the current study, the following observations may be made: (1) Halogen $(\mathrm{F}, \mathrm{Cl}, \mathrm{Br})$ substitution on both the meta and para positions of the benzyloxy ring enhances MAO-B inhibition compared to the unsubstituted derivative. Here, para substitution may be slightly more preferred than meta substitution. The effect of alkyl $\left(\mathrm{CH}_{3}\right.$ and $\left.\mathrm{CN}\right)$ substitution is much smaller and in some instances even reduces MAO-B inhibition potency (e.g. 4- $\mathrm{CH}_{3}$ ). The ortho fluorine-substituted compound is equipotent to the unsubstituted derivative. (2) In general, the 4-chromanones are weak MAO-A inhibitors. Chloro and bromo substitution in the para position, however, resulted in submicromolar inhibition. (3) In an attempt to identify a group and position (meta vs. para) that is most beneficial for MAO-B inhibition, halogen $(\mathrm{F}$, $\mathrm{Cl}, \mathrm{Br}$ ) substitution on the para position yielded compounds with $\mathrm{IC}_{50}<0.035 \mu \mathrm{M}$. As mentioned above, for MAO-A, chloro and bromo substitution in the para position yielded the best results. (4) It is interesting to note that besides benzyloxy substitution, 2-phenylethoxy, 3-phenylpropoxy and 
2-phenoxyethoxy substitution also leads to high-potency MAO-B inhibition, with these compounds exhibiting almost equipotent activities. With the exception of para chloro and fluoro substitution, further substitution with halogens and the methyl group does not significantly enhance MAO-B inhibition by the 2-phenoxyethoxy-substituted compounds. Para methyl substitution leads to a notable reduction in MAO-B inhibition. It is noteworthy that substitution with the isoamyloxy moiety $(\mathbf{2 q})$ results in particularly potent MAO-B inhibition, while it also yields good-potency MAO-A inhibition. (5) 2-Phenylethoxy and 3-phenylpropoxy substitution resulted in improved MAO-A inhibition compared to benzyloxy and 2-phenoxyethoxy substitution. It is particularly noteworthy that para chloro substitution of the 2-phenylethoxy-substituted compound $\mathbf{2 b}$ yielded the most potent MAO-A inhibitor among the 4-chromanones of the current study, compound $2 \mathbf{n}\left(\mathrm{IC}_{50}=0.286 \mu \mathrm{M}\right)$.

\section{Reversibility of MAO inhibition}

To determine the reversibility of MAO inhibition, the most potent MAO inhibitors among the 1-tetralol derivatives were selected as representative inhibitors. Alcohol derivatives were selected since the reversibility of inhibition of 1-tetralone and 4-chromanone derivatives has been investigated before [16, 19]. Reversibility of MAO inhibition is an important consideration since compounds which are reversible inhibitors, especially of MAO-A, have a reduced risk for causing the cheese reaction compared to irreversible inhibitors. Furthermore, for reversible

(a) MAO-A

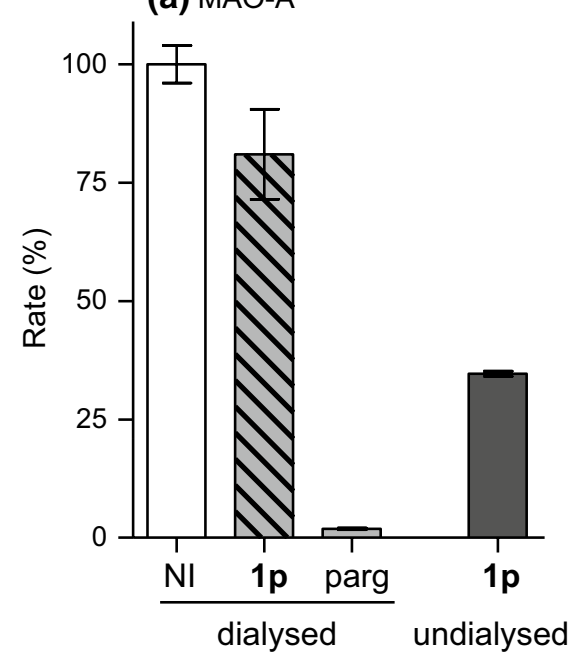

Fig. 5 Reversibility of inhibition of MAO-A (a) and MAO-B (b) by compounds 1p and 1o, respectively. MAO-A was preincubated in the absence of inhibitor (NI-dialysed) and the presence of $\mathbf{1 p}(\mathbf{1 p}-$ dialysed) and pargyline (parg-dialysed), and MAO-B was preincubated in the absence of inhibitor (NI-dialysed) and presence of 10 inhibition, enzyme activity is quickly recovered after drug withdrawal. Reversibility is thus a desired property in the design of MAO inhibitors. Reversibility is often evaluated by measuring the degree of recovery of enzyme activity after dialysis of mixtures containing the test inhibitor and enzyme [23]. In this study, 1-tetralol compounds $\mathbf{1 p}$ and $\mathbf{1 o}$ were selected as representative inhibitors for the evaluation of the reversibility of MAO-A and MAO-B inhibition, respectively.

MAO-A and MAO-B were firstly incubated with $\mathbf{1 p}$ and 1o, respectively, at concentrations equal to $4 \times \mathrm{IC}_{50}$. The samples were subsequently dialysed for $24 \mathrm{~h}$ and diluted twofold to yield an inhibitor concentration of $2 \times \mathrm{IC}_{50}$, and the residual enzyme activity was measured. As positive controls, MAO-A and MAO-B were similarly incubated and dialysed in the presence of the irreversible inhibitors, pargyline and (R)-deprenyl, respectively, while for the negative control, this experiment was carried out in the absence of inhibitor. For comparison, undialysed mixtures of the enzyme and test inhibitors were maintained over the same $24 \mathrm{~h}$ period and diluted and assayed as above.

After dialysis of mixtures of 1p and MAO-A, an almost complete recovery of MAO-A activity could be observed with the activity of MAO-A recovering to $81 \%$ of the control value (recorded in the absence of inhibitor) (Fig. 5). MAO-A inhibition by compound $\mathbf{1 p}$ is therefore reversible. In contrast, in undialysed mixtures of $\mathbf{1 p}$ and MAO-A, the residual activity was only $34 \%$. Dialysis of mixtures of pargyline and MAO-A resulted in no recovery of enzyme activity with residual activity at $1.9 \%$.

(b) MAO-B

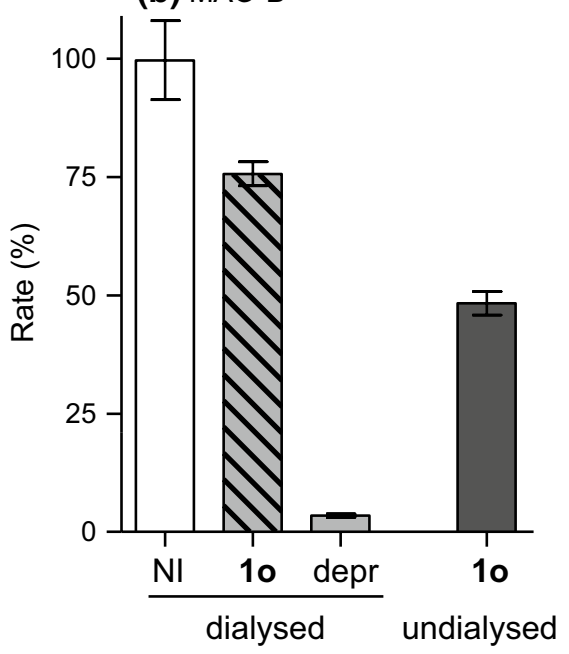

(1o-dialysed) and (R)-deprenyl (depr-dialysed). After dialysis, the residual enzyme activities were measured. For comparison, the MAO activities of undialysed mixtures of the MAOs and the test inhibitors were also measured (1p/10-undialysed) 
The inhibition of MAO-B by 10 also was reversible since dialysis of mixtures of $\mathbf{1 0}$ and MAO-B resulted in recovery of enzyme activity to $76 \%$ of the control value (Fig. 5). For undialysed mixtures of 10 and MAO-B, the residual enzyme activity was only $48 \%$. Dialysis of mixtures of (R)-deprenyl and MAO-B did not lead to recovery of enzyme activity with residual enzyme activity at only $3.5 \%$.

\section{Competitive mode of MAO inhibition}

The modes of inhibition (e.g. competitive or noncompetitive) of compounds $\mathbf{1 p}$ and $\mathbf{1 0}$ were examined using sets of Lineweaver-Burk plots. Compounds $\mathbf{1 p}$ and 10 were selected as representative inhibitors since they were the most potent MAO-A and MAO-B inhibitors, respectively, among the 1-tetralol derivatives, while the modes of inhibition have been investigated for tetralones [16]. The catalytic rates of MAO-A and MAO-B were measured at eight different kynuramine concentrations $(15-250 \mu \mathrm{M})$ in the absence and presence of five different concentrations of the test inhibitor (e.g. $1 / 4 \times \mathrm{IC}_{50}, 1 / 2 \times \mathrm{IC}_{50}, 3 / 4 \times \mathrm{IC}_{50}, 1 \times \mathrm{IC}_{50}$ and $\left.1 \frac{1}{4} \times \mathrm{IC}_{50}\right)$.

Examination of the Lineweaver-Burk plots shows that for both 1p and 1o, the lines are linear and intersect on the $y$-axis (Fig. 6). This is indicative of competitive inhibition and supports the finding that $\mathbf{1 p}$ and $\mathbf{1 0}$ are reversible inhibitors of MAO-A and MAO-B, respectively. From the replots of the slopes of the Lineweaver-Burk plots versus inhibitor concentration, $\mathrm{K}_{\mathrm{i}}$ values of $1.0 \mu \mathrm{M}$ and $0.0065 \mu \mathrm{M}$ are estimated for the inhibition of MAO-A and MAO-B by $\mathbf{1 p}$ and 1o, respectively.

\section{Conclusion}

This study investigates the MAO inhibition properties of a series of 1-tetralone and 4-chromanone derivatives and finds that these compounds are specific inhibitors of the MAO-B isoform. Among these series, 28 MAO-B inhibitors with submicromolar inhibition potencies are reported. Good-potency MAO-A inhibitors have also been identified, with eight compounds possessing submicromolar $\mathrm{IC}_{50}$ values. Highly potent MAO-B inhibitors were present among both series with 11 compounds exhibiting $\mathrm{IC}_{50}<0.01 \mu \mathrm{M}$. Reduction of 1-tetralones to the corresponding alcohols also yielded potent inhibition with, for example, 1p $\left(\mathrm{IC}_{50}=0.785 \mu \mathrm{M}\right)$ and $10\left(\mathrm{IC}_{50}=0.0075 \mu \mathrm{M}\right)$ being goodpotency inhibitors of MAO-A and MAO-B, respectively. These two compounds are reversible and competitive MAO inhibitors with $\mathrm{K}_{\mathrm{i}}$ values of $1.0 \mu \mathrm{M}$ and $0.0065 \mu \mathrm{M}$, respectively. Interestingly, the small molecule inhibitor $\mathbf{1 2}$ is a weak MAO inhibitor, which demonstrates the requirement for a substituent (e.g. benzyloxy, 2-phenylethoxy, 2-phenoxyethoxy) for MAO inhibition.
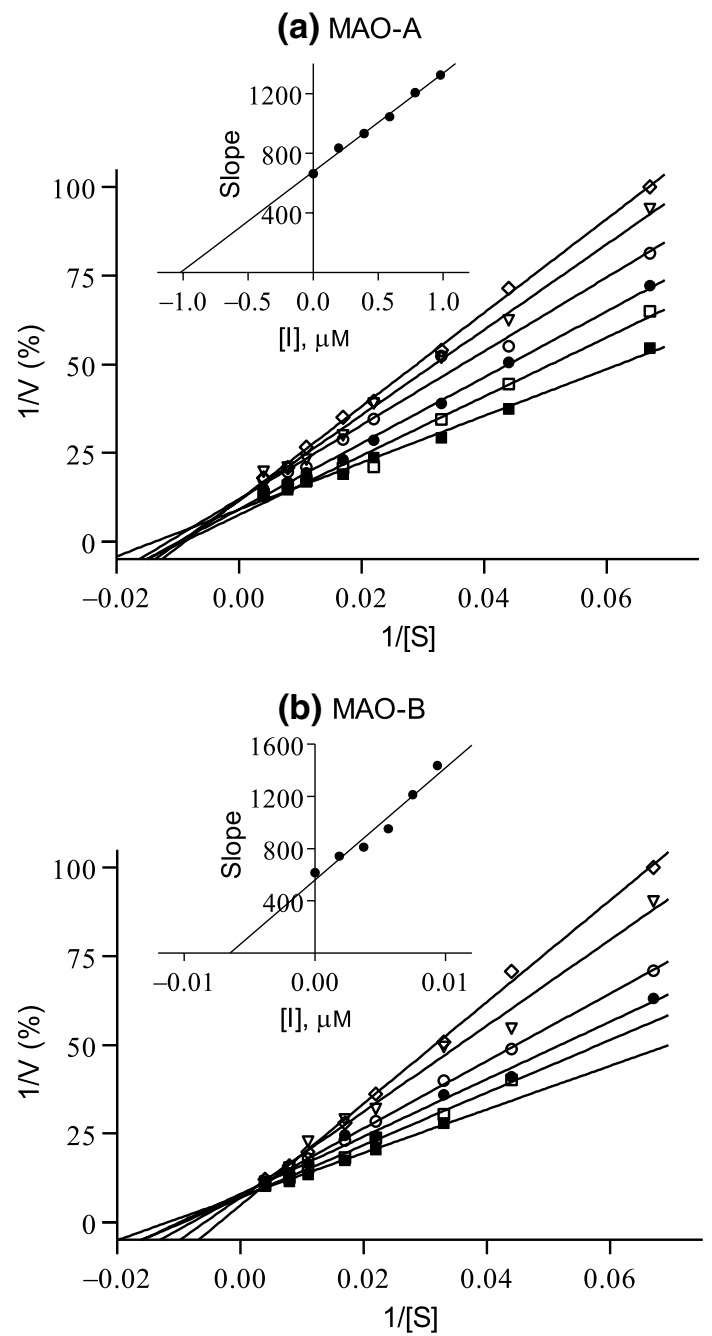

Fig. 6 Lineweaver-Burk plots for the activities of MAO-A (a) and MAO-B (b) in the absence and presence of 1p and 1o, respectively. The insets are replots of the slopes of the Lineweaver-Burk plots versus inhibitor concentration

Considering the MAO inhibition data of the 1-tetralone compounds of this study and those that have been reported in the literature, the following key conclusions may be made: (1) It is clear that substitution on $\mathrm{C} 7$ yields more potent inhibition of both MAO-A and MAO-B than substitution on C6, which in turn leads to more potent inhibition than substitution on C5. From a potency point of view, C7-substitution is thus most advantageous for MAO inhibition. (2) For both MAO-A and MAO-B, the chlorine-containing compounds are more potent inhibitors compared to the unsubstituted derivatives. This is observed for both the 1-tetralone and alcohol derivatives. (3) It is clear that both the 1-tetralone and alcohol derivatives are selective inhibitors of MAO-B over the MAO-A isoform.

Although the specific molecular interactions between the MAOs and the 1-tetralone (and alcohol) derivatives are not 
known, the reported crystal structures of the enzymes may provide some insight [28-30]. The active site of MAO-B is composed of an entrance cavity that leads to the substrate binding cavity where the flavin co-factor is located. While smaller substrates and inhibitors bind within the substrate cavity, larger compounds exhibit cavity-spanning binding modes and bind to both cavities. For example, safinamide binds with the polar amide in the substrate cavity, while the fluorobenzyloxy side chain extends into the entrance cavity [31]. The inhibitor therefore forms some polar interactions (e.g. hydrogen bonding) in the substrate cavity, while interactions in the entrance cavity are largely van der Waals interactions. Based on this, it seems likely that the inhibitors of the current study exhibit a similar binding mode to MAOB. The polar moiety (e.g. 1-tetralone, 1-tetralol and 4-chromanone) thus may bind within the substrate cavity, and the substituent (e.g. benzyloxy, 2-phenylethoxy, 2-phenoxyethoxy) extends into the entrance cavity. It could be proposed that $\mathrm{C} 7$ substitution yields cavity-spanning inhibitors that are better accommodated by the MAO-B active site and it forms more productive interactions compared to $\mathrm{C} 6$ and $\mathrm{C} 5$ substitution. For this reason, $\mathrm{C} 7$ substitution of 1-tetralone is more optimal for MAO-B inhibition. It may also be expected that the addition of a chlorine to the side chain will increase MAO-B inhibition potency since this will lead to additional van der Waals interactions. Similarly, the good MAO-B inhibition observed with the 4-chromanone derivatives may be dependent on the enhanced polarity of this moiety (compared to 1-tetralone) and thus the increased potential for polar interactions in the MAO-B substrate cavity.

In contrast to MAO-B, the active site of MAO-A is composed of a single cavity and accommodates smaller inhibitors better than larger compounds [28]. This is due to restrictions imposed by Phe-208 on the binding of larger inhibitors to MAO-A. It may thus be expected that the relatively larger compounds of this study will be less well accommodated in the MAO-A active site compared to MAO-B, which explains the specificity of MAO-B inhibition by the study compounds.

The large degree of MAO-B specificity of compounds $\mathbf{2 j}$, 2k and $\mathbf{2 l}$ cannot be explained by only considering the dimensions of the MAO-A vs. MAO-B active sites. Based on the limited space available in the MAO-A active site, it could have been anticipated that these larger inhibitors would not be able to bind to MAO-A and therefore act as specific MAO-B inhibitors. As pointed out above, some compounds such as $\mathbf{1 h}$ and $\mathbf{2 n}$ exhibit good MAO-A inhibition although being relatively large molecules. While generalisations regarding optimal structural features for inhibitor binding can be useful, the complexities of ligand interactions, induced fit and the similarity between the MAO-A and MAO-B active sites could have unpredictable consequences on inhibitor binding and interaction.
It must be acknowledged that while the above consideration of the MAO active sites does provide some insight into the specificities and potencies of the study compounds, it cannot explain all the inhibition data presented here. For example, small structural modifications (e.g. 2b vs. 2m) may result in a large effect on MAO-B inhibition potency. For $\mathbf{2 b}$ vs. $\mathbf{2 m}$, with the addition of the methoxy group, it may have been expected that MAO-B inhibition potency should increase. In contrast, a large reduction in MAO-B inhibition was observed. Similarly, some compounds exhibit good MAO-A inhibition (e.g. 1h, 2n and others) although being relatively large molecules. Considering the limited size of the active site of MAO-A, it may have been expected that such compounds would not act as MAO-A inhibitors. These unexpected findings are probably the result of complex processes that involve induced fit and multiple interactions that cannot be predicted.

\section{Experimental section}

\section{Materials and methods}

Starting materials (reagents and solvents) that were used in this study were obtained from Sigma-Aldrich and were used without further purification. TLC was carried out to determine whether the reactions proceeded to completion and were carried out using silica gel sheets containing UV254 fluorescent indicator. The developed TLC sheets were observed under an UV lamp at a wavelength of $254 \mathrm{~nm}$. A Büchi B-545 melting-point apparatus was used to measure the melting points of all of the synthesised compounds. High-resolution mass spectra (HRMS) were obtained with a Bruker micrOTOF-Q II mass spectrometer in atmospheric-pressure chemical ionisation (APCI) mode. A Bruker Avance III 600 spectrometer was used to record proton $\left({ }^{1} \mathrm{H}\right)$ and carbon $\left({ }^{13} \mathrm{C}\right)$ NMR spectra at frequencies of $600 \mathrm{MHz}$ and $150 \mathrm{MHz}$, respectively. NMR measurements were conducted in $\mathrm{CDCl}_{3}$ or DMSO- $d 6$, and the chemical shifts are reported in parts per million $(\delta)$. Chemical shifts were referenced to the residual solvent signals for $\mathrm{CDCl}_{3}$ at $7.26 \mathrm{ppm}$ and $77.16 \mathrm{ppm}$, and for DMSO- $d 6$ at 2.50 and $39.52 \mathrm{ppm}$ for ${ }^{1} \mathrm{H}$ and ${ }^{13} \mathrm{C}$, respectively. Spin multiplicities are given as s (singlet), d (doublet), dd (doublet of doublets), dt (doublet of triplets), $t$ (triplet) or $\mathrm{m}$ (multiplet). The coupling constants (J) are given in $\mathrm{Hz}$. Microsomes from insect cells containing recombinant human MAO-A and MAO-B (5 mg protein/ $\mathrm{mL}$ ), kynuramine dihydrobromide, (R)-deprenyl and pargyline were obtained from Sigma-Aldrich. A Varian Cary Eclipse fluorescence spectrophotometer was used to determine fluorescence intensities. 


\section{Purity determination of synthesised compounds}

HPLC analyses were conducted with an Agilent 1200 HPLC system equipped with a quaternary pump and an Agilent 1200 series diode array detector. The HPLC analyses were used to determine the purities of the synthesised compounds. HPLC-grade acetonitrile (Merck) and Milli-Q water (Millipore) were used for the chromatography. A Venusil XBP C18 column $(4.60 \times 150 \mathrm{~mm}, 5 \mu \mathrm{m})$ was used for the separation, and the mobile phase consisted at the start of each run of $30 \%$ acetonitrile and $70 \%$ Milli-Q water. The flow rate was set to $1 \mathrm{ml} / \mathrm{min}$. At the start of each run, a solvent gradient program was initiated. The composition of the acetonitrile in the mobile phase was increased linearly to $80 \%$ over a period of $5 \mathrm{~min}$. Each HPLC run lasted $15 \mathrm{~min}$, and a time period of $5 \mathrm{~min}$ was allowed for equilibration between runs. A volume of $20 \mu \mathrm{L}$ of solutions of the test compounds ( $1 \mathrm{mM}$ dissolved in acetonitrile) was injected into the HPLC system, and the eluent was monitored at a wavelength of $254 \mathrm{~nm}$.

\section{Synthesis of 5-, 6- and 7-hydroxy-1-tetralones (8a-c)}

The key starting materials, 5-, 6- and 7-hydroxy-1-tetralone $(\mathbf{8 a}-\mathbf{c})$, were synthesised as reported in the literature [15]. The corresponding methoxy-1-tetralone derivatives $\mathbf{7 a - c}$ (10 mmol) were added to aluminium chloride $\left(\mathrm{AlCl}_{3}\right)$ $(25 \mathrm{mmol})$ and toluene $(50 \mathrm{~mL})$ in a round-bottom flask. The reaction was heated under reflux for $1 \mathrm{~h}$. Silica gel TLC was used to determine whether the reaction has proceeded to completion [ethyl acetate $(30 \%)$, petroleum ether $(70 \%)$ ]. The reaction was placed on ice for $30 \mathrm{~min}$, and water $(75 \mathrm{~mL})$ was cautiously added to the reaction. The mixture was subsequently extracted to ethyl acetate $(3 \times 75 \mathrm{~mL})$. The combined organic phases were dried over anhydrous $\mathrm{MgSO}_{4}$, the organic phase was evaporated under reduced pressure and the crude product was purified by recrystallisation from ethyl acetate.

\section{Synthesis of substituted 1-tetralone derivatives (1a-h)}

5-, 6- or 7-Hydroxy-1-tetralone (8a-c) (10 mmol) was added to a round-bottom flask containing $100 \mathrm{~mL}$ acetone. Anhydrous potassium carbonate $\left(\mathrm{K}_{2} \mathrm{CO}_{3}\right)(20 \mathrm{mmol})$ and the appropriate substituted alkyl bromide $(11.2 \mathrm{mmol})$ were added. The reaction was heated under reflux for $20 \mathrm{~h}$. Silica gel TLC was used to determine whether the reactants have been consumed indicating completion of the reaction [ethyl acetate $(30 \%)$, petroleum ether $(70 \%)$ ]. The remaining $\mathrm{K}_{2} \mathrm{CO}_{3}$ was removed from the reaction by filtration. The organic phase was evaporated under reduced pressure, and the residue was recrystallised from cyclohexane [15].

\section{Synthesis of 1-tetralol derivatives (1i-p)}

In a round-bottom flask, 1-tetralone derivatives $\mathbf{1 a - h}$ (10 mmol) were dissolved in $100 \mathrm{~mL}$ ethanol. Sodium borohydride $(20 \mathrm{mmol})$ was added, and the reaction was heated under reflux for $18 \mathrm{~h}$. Silica gel TLC was used to determine whether the reactants have been consumed indicating completion of the reaction [ethyl acetate $(30 \%)$, petroleum ether $(70 \%)]$. The solvent was removed under reduced pressure, and water $(100 \mathrm{~mL})$ was cautiously added to the reaction. The resulting mixture was extracted to dichloromethane $(3 \times 75 \mathrm{~mL})$, the organic phase was dried over anhydrous $\mathrm{MgSO}_{4}$ and the organic phase was evaporated under reduced pressure. The residue was subsequently purified by recrystallisation from cyclohexane to give the target alcohols $\mathbf{1 i}-\mathbf{p}$.

\section{Synthesis of 7-hydroxy-4-chromanone (12)}

To a mixture of resorcinol $(\mathbf{9}, 10.0 \mathrm{mmol})$ and 3 -chloropropionic acid $(\mathbf{1 0}, 10.1 \mathrm{mmol})$ was slowly added trifluoromethanesulfonic acid $(5 \mathrm{~mL})$. The solution was stirred at $80{ }^{\circ} \mathrm{C}$ for $1.5 \mathrm{~h}$ and poured into dichloromethane $(100 \mathrm{~mL})$. The resulting solution was poured into water $(100 \mathrm{~mL})$, and the aqueous layer was extracted to dichloromethane $(2 \times 100 \mathrm{~mL})$. The combined organic layers were dried over anhydrous $\mathrm{MgSO}_{4}$ and evaporated under reduced pressure. The resulting product (11) was used directly in the next reaction without further purification. $\mathrm{NaOH}(2 \mathrm{~N} ; 400 \mathrm{~mL})$ was added to the crude product, and the resulting mixture was stirred at $0{ }^{\circ} \mathrm{C}$ for $4 \mathrm{~h}$. After the reaction has completed, the $\mathrm{pH}$ was adjusted to 2 with concentrated $\mathrm{HCl}$. The reaction was extracted to ethyl acetate $(3 \times 100 \mathrm{~mL})$, washed with brine, dried over anhydrous $\mathrm{MgSO}_{4}$ and concentrated under reduced pressure. The desired product, 7-hydroxy-4-chromanone (12), was obtained by recrystallisation from ethyl acetate/n-hexane (1:5) [21].

\section{Synthesis of substituted 4-chromanone derivatives $(2 a-q)$}

A mixture of 7-hydroxy-4-chromanone (12, $11.3 \mathrm{mmol})$, an appropriately substituted arylalkyl bromide (11.6 mmol), and $\mathrm{K}_{2} \mathrm{CO}_{3}(15.2 \mathrm{mmol})$ in acetone $(110 \mathrm{~mL})$ was heated under reflux for $20 \mathrm{~h}$. The reaction was cooled and filtered through a pad of Celite. The filtrate was evaporated under reduced pressure, and the residue was dissolved in ethyl acetate. The organic phase was washed with water and brine, dried over $\mathrm{MgSO}_{4}$, concentrated under reduced pressure and dried at $40{ }^{\circ} \mathrm{C}$. Recrystallisation from ethylacetate/n-hexane (1:5) yielded the product. 


\section{5-Benzyloxy-1-tetralone (1a)}

Melting point: oil; purity: $98.5 \%$; yield: $38.3 \%$ (final step). ${ }^{1} \mathrm{H}$ NMR (600 MHz, chloroform- $d$ ) $\delta 7.60$ (dd, $J=7.9,1.1 \mathrm{~Hz}, 1 \mathrm{H}), 7.39-7.35(\mathrm{~m}, 2 \mathrm{H}), 7.35-7.31(\mathrm{~m}$, 2H), 7.31-7.24 (m, 1H), 7.21-7.15 (m, 1H), $7.01(\mathrm{dd}$, $J=8.1,1.1 \mathrm{~Hz}, 1 \mathrm{H}), 5.03(\mathrm{~s}, 2 \mathrm{H}), 2.90(\mathrm{t}, J=6.2 \mathrm{~Hz}$, 2H), 2.59-2.53 (m, 2H), 2.08-2.01 (m, 2H). ${ }^{13} \mathrm{C} \mathrm{NMR}$ $\left(151 \mathrm{MHz}, \mathrm{CDCl}_{3}\right) \delta 198.65,155.90,136.81,133.95$, 133.79, 128.63, 128.04, 127.20, 126.73, 119.11, 115.76, 70.33, 38.86, 23.04, 22.54. APCI-HRMS $m / z$ : calculated for $\mathrm{C}_{17} \mathrm{H}_{17} \mathrm{O}_{2}\left(\mathrm{MH}^{+}\right)$, 253.1223, found 253.1216.

\section{6-Benzyloxy-1-tetralone (1 b)}

Melting point: $100.6-106.2{ }^{\circ} \mathrm{C}$, lit. $100.9-102.1{ }^{\circ} \mathrm{C}$ [15]; purity: $99.8 \%$; yield (final step): $76.3 \% .{ }^{1} \mathrm{H}$ NMR $\left(600 \mathrm{MHz}, \mathrm{CDCl}_{3}\right) \delta 7.93(\mathrm{~d}, J=8.8 \mathrm{~Hz}, 1 \mathrm{H}), 7.37-7.27$ (m, 4H), 7.30-7.24 (m, 1H), 6.82(dd, $J=8.7,2.6 \mathrm{~Hz}, 1 \mathrm{H})$, $6.71(\mathrm{~d}, J=2.4 \mathrm{~Hz}, 1 \mathrm{H}), 5.03(\mathrm{~s}, 2 \mathrm{H}), 2.84(\mathrm{t}, J=6.1 \mathrm{~Hz}$, $2 \mathrm{H}), 2.53(\mathrm{t}, J=7.0 \mathrm{~Hz}, 2 \mathrm{H}), 2.07-1.99(\mathrm{~m}, 2 \mathrm{H}) .{ }^{13} \mathrm{C} \mathrm{NMR}$ $\left(151 \mathrm{MHz}, \mathrm{CDCl}_{3}\right) \delta 197.18,162.69,146.96,136.23$, $129.68,128.70,128.23,127.48,126.53,113.70,113.59$, 70.06, 38.92, 30.17, 23.37. APCI-HRMS $m / z$ : calculated for $\mathrm{C}_{17} \mathrm{H}_{17} \mathrm{O}_{2}\left(\mathrm{MH}^{+}\right), 253.1223$, found 253.1202 .

\section{7-Benzyloxy-1-tetralone (1c)}

Melting point: $87.6-88.3{ }^{\circ} \mathrm{C}$, lit. $86.4-87.1^{\circ} \mathrm{C}$ [16]; purity: 99.7\%; yield (final step): $77.2 \% .{ }^{1} \mathrm{H}$ NMR $(600 \mathrm{MHz}$, $\left.\mathrm{CDCl}_{3}\right) \delta 7.54(\mathrm{~d}, J=2.8 \mathrm{~Hz}, 1 \mathrm{H}), 7.39-7.34(\mathrm{~m}, 2 \mathrm{H}), 7.31$ $(\mathrm{t}, J=7.8 \mathrm{~Hz}, 2 \mathrm{H}), 7.28-7.23(\mathrm{~m}, 1 \mathrm{H}), 7.09(\mathrm{~d}, J=8.4 \mathrm{~Hz}$, $1 \mathrm{H}), 7.05(\mathrm{dd}, J=8.4,2.8 \mathrm{~Hz}, 1 \mathrm{H}), 5.01(\mathrm{~s}, 2 \mathrm{H}), 2.82(\mathrm{t}$, $J=6.1 \mathrm{~Hz}, 2 \mathrm{H}), 2.56(\mathrm{t}, J=6.9 \mathrm{~Hz}, 2 \mathrm{H}), 2.07-2.00(\mathrm{~m}$, 2H). $\left.{ }^{13} \mathrm{C} \mathrm{NMR} \mathrm{(151} \mathrm{MHz,} \mathrm{CDCl}_{3}\right) \delta 198.31,157.48$, 137.41, 136.68, 133.39, 130.07, 128.60, 128.04, 127.58, $122.36,110.27,70.17,39.01,28.92,23.49$. APCI-HRMS $m / z$ : calculated for $\mathrm{C}_{17} \mathrm{H}_{17} \mathrm{O}_{2}\left(\mathrm{MH}^{+}\right), 253.1223$, found 253.1243 .

\section{5-(2-Phenoxyethoxy)-1-tetralone (1d)}

Melting point: $135.6-144.0{ }^{\circ} \mathrm{C}$; purity: $99.8 \%$; yield (final step): $66.6 \% .{ }^{1} \mathrm{H}$ NMR $\left(600 \mathrm{MHz}, \mathrm{CDCl}_{3}\right) \delta 7.60(\mathrm{~d}$, $J=7.9 \mathrm{~Hz}, 1 \mathrm{H}), 7.26-7.21(\mathrm{~m}, 2 \mathrm{H}), 7.21-7.17(\mathrm{~m}, 1 \mathrm{H})$, $6.99(\mathrm{~d}, J=8.0 \mathrm{~Hz}, 1 \mathrm{H}), 6.92(\mathrm{~d}, J=7.1 \mathrm{~Hz}, 1 \mathrm{H}), 6.89$ (d, $J=8.4 \mathrm{~Hz}, 2 \mathrm{H}), 4.28(\mathrm{~s}, 4 \mathrm{H}), 2.82(\mathrm{t}, J=6.2 \mathrm{~Hz}, 2 \mathrm{H}), 2.54$ $(\mathrm{t}, J=6.4 \mathrm{~Hz}, 2 \mathrm{H}), 2.05-1.98(\mathrm{~m}, 2 \mathrm{H}) .{ }^{13} \mathrm{C}$ NMR $(151 \mathrm{MHz}$, $\left.\mathrm{CDCl}_{3}\right) \delta 198.64,158.63,155.91,134.05,133.79,129.57$, 126.71, 121.21, 119.32, 115.68, 114.69, 67.29, 66.46, 38.85,
22.90, 22.50. APCI-HRMS $m / z$ : calculated for $\mathrm{C}_{18} \mathrm{H}_{19} \mathrm{O}_{3}$ $\left(\mathrm{MH}^{+}\right), 283.1329$, found 283.1349.

\section{6-(2-Phenoxyethoxy)-1-tetralone (1e)}

Melting point: $107.0-128.1{ }^{\circ} \mathrm{C}$; purity: $98.2 \%$; yield (final step): $60.2 \% .{ }^{1} \mathrm{H}$ NMR $\left(600 \mathrm{MHz}, \mathrm{CDCl}_{3}\right) \delta 7.94(\mathrm{~d}$, $J=8.7 \mathrm{~Hz}, 1 \mathrm{H}), 7.27-7.20(\mathrm{~m}, 2 \mathrm{H}), 6.96-6.85(\mathrm{~m}, 3 \mathrm{H})$, $6.80(\mathrm{dd}, J=8.7,2.6 \mathrm{~Hz}, 1 \mathrm{H}), 6.69(\mathrm{~d}, J=2.5 \mathrm{~Hz}, 1 \mathrm{H})$, $4.33-4.24(\mathrm{~m}, 4 \mathrm{H}), 2.85(\mathrm{t}, J=6.1 \mathrm{~Hz}, 2 \mathrm{H}), 2.57-2.51(\mathrm{~m}$, 2H), 2.08-2.00 (m, 2H). ${ }^{13} \mathrm{C}$ NMR (151 MHz, $\left.\mathrm{CDCl}_{3}\right) \delta$ 197.20, 162.56, 158.46, 146.96, 129.68, 129.55, 126.62, $121.25,114.66,113.47,113.42,66.61,66.20,38.92,38.16$, $31.26,30.15,29.71,23.37,14.14$. APCI-HRMS $m / z$ : calculated for $\mathrm{C}_{18} \mathrm{H}_{19} \mathrm{O}_{3}\left(\mathrm{MH}^{+}\right), 283.1329$, found 283.1313.

\section{7-(2-Phenoxyethoxy)-1-tetralone (1f)}

Melting point: $115.6-118.4{ }^{\circ} \mathrm{C}$; purity: $99.7 \%$; yield (final step): 83.7\%. ${ }^{1} \mathrm{H}$ NMR (600 MHz, $\left.\mathrm{CDCl}_{3}\right) \delta 7.49$ (d, $J=2.8 \mathrm{~Hz}, 1 \mathrm{H}), 7.25-7.18(\mathrm{~m}, 2 \mathrm{H}), 7.10(\mathrm{~d}, J=8.4 \mathrm{~Hz}, 1 \mathrm{H})$, $7.04(\mathrm{dd}, J=8.4,2.8 \mathrm{~Hz}, 1 \mathrm{H}), 6.92-6.85(\mathrm{~m}, 3 \mathrm{H}), 4.31-4.27$ (m, 2H), 4.27-4.22 (m, 2H), $2.83(\mathrm{t}, J=6.1 \mathrm{~Hz}, 2 \mathrm{H}), 2.56(\mathrm{t}$, $J=6.8 \mathrm{~Hz}, 2 \mathrm{H}), 2.11-2.00(\mathrm{~m}, 2 \mathrm{H}) .{ }^{13} \mathrm{C} \mathrm{NMR}(151 \mathrm{MHz}$, $\left.\mathrm{CDCl}_{3}\right) \delta 198.31,158.57,157.37,137.57,133.35,130.11$, 129.51, 122.48, 121.13, 114.70, 109.84, 66.79, 66.37, 39.00, 28.91, 23.49. APCI-HRMS $m / z$ : calculated for $\mathrm{C}_{18} \mathrm{H}_{19} \mathrm{O}_{3}$ $\left(\mathrm{MH}^{+}\right), 283.1329$, found 283.1339 .

\section{6-(4-Chlorobenzyloxy)-1-tetralone (1 g)}

Melting point: $96.1-98.2{ }^{\circ} \mathrm{C}$, lit. $96.6-98.7^{\circ} \mathrm{C}$ [15]; purity: 99.7\%; yield (final step): $48.2 \% .{ }^{1} \mathrm{H}$ NMR $(600 \mathrm{MHz}$, $\left.\mathrm{CDCl}_{3}\right) \delta 7.94(\mathrm{~d}, J=8.7 \mathrm{~Hz}, 1 \mathrm{H}), 7.32-7.26(\mathrm{~m}, 4 \mathrm{H}), 6.80$ $(\mathrm{dd}, J=8.7,2.6 \mathrm{~Hz}, 1 \mathrm{H}), 6.69(\mathrm{~d}, 1 \mathrm{H}), 5.00(\mathrm{~s}, 2 \mathrm{H}), 2.84$ $(\mathrm{t}, J=6.1 \mathrm{~Hz}, 2 \mathrm{H}), 2.53(\mathrm{t}, J=6.8 \mathrm{~Hz}, 2 \mathrm{H}), 2.08-2.00(\mathrm{~m}$, 2H). ${ }^{13} \mathrm{C} \mathrm{NMR}\left(151 \mathrm{MHz}, \mathrm{CDCl}_{3}\right) \delta 197.13,162.38,146.98$, 134.73, 134.05, 129.72, 128.88, 128.76, 126.69, 113.63, $113.59,69.24,38.90,30.15,23.34$. APCI-HRMS $\mathrm{m} / \mathrm{z}$ : calculated for $\mathrm{C}_{17} \mathrm{H}_{16} \mathrm{ClO}_{2}\left(\mathrm{MH}^{+}\right)$, 287.0833, found 287.0857.

\section{7-(4-Chlorobenzyloxy)-1-tetralone (1h)}

Melting point: $93.6-95.8{ }^{\circ} \mathrm{C}$, lit. $92.7-93.6^{\circ} \mathrm{C}$ [16]; purity: 99.8\%; yield (final step): $73.4 \% .{ }^{1} \mathrm{H}$ NMR $(600 \mathrm{MHz}$, $\left.\mathrm{CDCl}_{3}\right) \delta 7.51(\mathrm{~d}, J=2.8 \mathrm{~Hz}, 1 \mathrm{H}), 7.32-7.25(\mathrm{~m}, 4 \mathrm{H}), 7.10$ $(\mathrm{d}, J=8.3 \mathrm{~Hz}, 1 \mathrm{H}), 7.03(\mathrm{dd}, J=8.4,2.8 \mathrm{~Hz}, 1 \mathrm{H}), 4.98$ (s, 2H), 2.83 (t, $J=6.1 \mathrm{~Hz}, 2 \mathrm{H}), 2.56(\mathrm{t}, J=6.5 \mathrm{~Hz}, 2 \mathrm{H}$ ), 2.08-2.00 (m, 2H). ${ }^{13} \mathrm{C}$ NMR (151 MHz, $\left.\mathrm{CDCl}_{3}\right) \delta 198.24$, $157.19,137.60,135.20,133.82,133.40,130.15,128.85$, $128.77,122.32,110.24,69.34,38.98,28.91,23.46$. APCIHRMS $m / z$ : calculated for $\mathrm{C}_{17} \mathrm{H}_{16} \mathrm{ClO}_{2}\left(\mathrm{MH}^{+}\right), 287.0833$, found 287.0839 . 


\section{5-Benzyloxy-1-tetralol (1i)}

Melting point: $86.1-89.9{ }^{\circ} \mathrm{C}$; purity: $99.6 \%$; yield (final step): 43.8\%. ${ }^{1} \mathrm{H}$ NMR $\left(600 \mathrm{MHz}, \mathrm{CDCl}_{3}\right) \delta 7.35(\mathrm{~d}$, $J=7.2 \mathrm{~Hz}, 2 \mathrm{H}), 7.30(\mathrm{t}, J=7.3 \mathrm{~Hz}, 1 \mathrm{H}), 7.28-7.20(\mathrm{~m}, 1 \mathrm{H})$, 7.09 (t, $J=7.9 \mathrm{~Hz}, 1 \mathrm{H}), 7.00(\mathrm{~d}, J=7.7 \mathrm{~Hz}, 1 \mathrm{H}), 6.73$ (dd, $J=8.0,1.1 \mathrm{~Hz}, 1 \mathrm{H}), 4.99$ (s, 2H), 4.69 (s, 1H), 2.81-2.73 (m, 1H), 2.60-2.51 (m, 1H), 1.93-1.82 (m, 2H), 1.82-1.76 (m, 1H), $1.75-1.66(\mathrm{~m}, 2 \mathrm{H}) .{ }^{13} \mathrm{C}$ NMR $\left(151 \mathrm{MHz}, \mathrm{CDCl}_{3}\right)$ $\delta 156.15,140.20,137.38,128.54,127.79,127.08,126.53$, 126.51, 120.84, 110.08, 69.82, 68.20, 31.76, 23.24, 18.08 . APCI-HRMS $m / z$ : calculated for $\mathrm{C}_{17} \mathrm{H}_{18} \mathrm{O}_{2}\left(\mathrm{M}^{+}\right), 254.1307$, found 254.1295.

\section{6-Benzyloxy-1-tetralol (1j)}

Melting point: $59.5-93.5{ }^{\circ} \mathrm{C}$; purity: $98.9 \%$; yield (final step): $70.5 \% .{ }^{1} \mathrm{H}$ NMR $\left(600 \mathrm{MHz}, \mathrm{DCl}_{3}\right) \delta 7.36-7.31$ (m, $2 \mathrm{H}), 7.29(\mathrm{t}, J=8.2 \mathrm{~Hz}, 2 \mathrm{H}), 7.25-7.21(\mathrm{~m}, 2 \mathrm{H}), 6.75(\mathrm{dd}$, $J=8.5,2.7 \mathrm{~Hz}, 1 \mathrm{H}), 6.62(\mathrm{~d}, J=2.7 \mathrm{~Hz}, 1 \mathrm{H}), 4.95(\mathrm{~s}, 2 \mathrm{H})$, $4.64(\mathrm{t}, J=4.3 \mathrm{~Hz}, 1 \mathrm{H}), 2.74-2.66(\mathrm{~m}, 1 \mathrm{H}), 2.65-2.55(\mathrm{~m}$, $1 \mathrm{H}), 1.91-1.77(\mathrm{~m}, 2 \mathrm{H}), 1.73-1.61(\mathrm{~m}, 2 \mathrm{H}) .{ }^{13} \mathrm{C} \mathrm{NMR}$ $\left(151 \mathrm{MHz}, \mathrm{CDCl}_{3}\right) \delta 158.11,138.68,137.08,131.55$, $130.13,128.60,127.95,127.45,114.45,113.26,69.95$, 67.65, 32.40, 29.63, 18.61. APCI-HRMS $\mathrm{m} / z$ : calculated for $\mathrm{C}_{17} \mathrm{H}_{18} \mathrm{O}_{2}\left(\mathrm{M}^{+}\right), 254.1307$, found 254.1277.

\section{7-Benzyloxy-1-tetralol (1 k)}

Melting point: $57.2-59.9{ }^{\circ} \mathrm{C}$; purity: $99.9 \%$; yield (final step): $79.9 \% .{ }^{1} \mathrm{H}$ NMR $\left(600 \mathrm{MHz}, \mathrm{CDCl}_{3}\right) \delta 7.38-7.33$ (m, 2H), 7.33-7.27 (m, 1H), 7.27-7.20 (m, 1H), $7.00(\mathrm{~d}$, $J=2.7 \mathrm{~Hz}, 1 \mathrm{H}), 6.94(\mathrm{~d}, J=8.6 \mathrm{~Hz}, 1 \mathrm{H}), 6.77$ (dd, $J=8.4$, $2.7 \mathrm{~Hz}, 1 \mathrm{H}), 4.97(\mathrm{~d}, J=1.8 \mathrm{~Hz}, 2 \mathrm{H}), 4.65(\mathrm{t}, J=5.3 \mathrm{~Hz}, 1 \mathrm{H})$, 2.71-2.63 (m, 1H), 2.62-2.54 (m, 1H), 1.96-1.81 (m, 2H), $1.82-1.74(\mathrm{~m}, 1 \mathrm{H}), 1.72-1.63(\mathrm{~m}, 1 \mathrm{H}) .{ }^{13} \mathrm{C}$ NMR $(151 \mathrm{MHz}$, $\left.\mathrm{CDCl}_{3}\right) \delta 157.20,139.89,137.15,129.99,129.44,128.57$, 127.91, 127.50, 115.11, 113.80, 70.08, 68.48, 32.41, 28.47, 19.20. APCI-HRMS $m / z$ : calculated for $\mathrm{C}_{17} \mathrm{H}_{18} \mathrm{O}_{2}\left(\mathrm{M}^{+}\right)$, 254.1307, found 254.1305.

\section{5-(2-Phenoxyethoxy)-1-tetralol (1I)}

Melting point: $102.3-103.4{ }^{\circ} \mathrm{C}$; purity: $99.6 \%$; yield (final step): $90.8 \% .{ }^{1} \mathrm{H}$ NMR $\left(600 \mathrm{MHz}, \mathrm{CDCl}_{3}\right) \delta 7.26-7.16$ $(\mathrm{m}, 2 \mathrm{H}), 7.11(\mathrm{t}, J=7.9 \mathrm{~Hz}, 1 \mathrm{H}), 7.01(\mathrm{~d}, J=7.7 \mathrm{~Hz}, 1 \mathrm{H})$, 6.93-6.85 (m, 3H), $6.72(\mathrm{dd}, J=8.1,1.1 \mathrm{~Hz}, 1 \mathrm{H}), 4.72-4.66$ (m, 1H), 4.29-4.20 (m, 4H), $2.70(\mathrm{dt}, J=17.4,5.4 \mathrm{~Hz}, 1 \mathrm{H})$, 2.53-2.44 (m, 1H), 1.91-1.74 (m, 3H), 1.74-1.65 (m, 1H). ${ }^{13} \mathrm{C}$ NMR $\left(151 \mathrm{MHz}, \mathrm{CDCl}_{3}\right) \delta 158.72,156.09,140.24$, 129.52, 126.64, 126.50, 121.08, 121.02, 114.73, 109.98, $68.19,66.80,66.54,31.74,23.06,18.03$. APCI-HRMS m/z: calculated for $\mathrm{C}_{18} \mathrm{H}_{20} \mathrm{O}_{3}\left(\mathrm{M}^{+}\right)$, 284.1412, found 284.1416.

\section{6-(2-Phenoxyethoxy)-1-tetralol (1 m)}

Melting point: $116.8-117.7^{\circ} \mathrm{C}$; purity: $98.3 \%$; yield (final step): 44.9\%. ${ }^{1} \mathrm{H}$ NMR $\left(600 \mathrm{MHz}, \mathrm{CDCl}_{3}\right) \delta 7.26(\mathrm{~d}$, $J=8.5 \mathrm{~Hz}, 1 \mathrm{H}), 7.26-7.18(\mathrm{~m}, 2 \mathrm{H}), 6.92-6.84(\mathrm{~m}, 3 \mathrm{H})$, $6.74(\mathrm{dd}, J=8.5,2.7 \mathrm{~Hz}, 1 \mathrm{H}), 6.60(\mathrm{~d}, J=2.5 \mathrm{~Hz}, 1 \mathrm{H})$, 4.69-4.64 (m, 1H), $4.23(\mathrm{~s}, 4 \mathrm{H}), 2.71(\mathrm{dt}, J=17.3,4.3 \mathrm{~Hz}$, 1H), 2.66-2.57 (m, 1H), 1.93-1.79 (m, 2H), 1.73-1.64 (m, $1 \mathrm{H}), 1.61(\mathrm{~s}, 1 \mathrm{H}) .{ }^{13} \mathrm{C}$ NMR $\left(151 \mathrm{MHz}, \mathrm{CDCl}_{3}\right) \delta 158.60$, 157.94, 138.69, 131.70, 130.12, 129.51, 121.10, 114.70, $114.31,113.15,67.65,66.51,66.42,32.40,29.61,18.59$. APCI-HRMS $m / z$ : calculated for $\mathrm{C}_{18} \mathrm{H}_{20} \mathrm{O}_{3}\left(\mathrm{M}^{+}\right), 284.1412$, found 284.1384 .

\section{7-(2-Phenoxyethoxy)-1-tetralol (1n)}

Melting point: $103.4-106.5^{\circ} \mathrm{C}$; purity: $98.6 \%$; yield (final step): $50.5 \% .{ }^{1} \mathrm{H}$ NMR $\left(600 \mathrm{MHz}, \mathrm{CDCl}_{3}\right) \delta$ 7.27-7.19 (m, 2H), 6.99-6.92 (m, 2H), 6.92-6.83 (m, 3H), $6.75(\mathrm{dd}$, $J=8.4,2.7 \mathrm{~Hz}, 1 \mathrm{H}), 4.69-4.62(\mathrm{~m}, 1 \mathrm{H}), 4.24(\mathrm{~d}, J=2.2 \mathrm{~Hz}$, $4 \mathrm{H}), 2.68(\mathrm{dt}, J=16.4,5.9 \mathrm{~Hz}, 1 \mathrm{H}), 2.63-2.53(\mathrm{~m}, 1 \mathrm{H})$, $1.99-1.82(\mathrm{~m}, 2 \mathrm{H}), 1.82-1.73(\mathrm{~m}, 1 \mathrm{H}), 1.72-1.62(\mathrm{~m}, 2 \mathrm{H})$. ${ }^{13} \mathrm{C} \mathrm{NMR}\left(151 \mathrm{MHz}, \mathrm{CDCl}_{3}\right) \delta 158.63,157.04,139.91$, 130.01, 129.60, 129.50, 121.07, 115.08, 114.71, 113.63, 68.48, 66.67, 66.48, 32.42, 28.46, 19.20. APCI-HRMS m/z: calculated for $\mathrm{C}_{18} \mathrm{H}_{20} \mathrm{O}_{3}\left(\mathrm{M}^{+}\right)$, 284.1412, found 284.1410.

\section{6-(4-Chlorobenzyloxy)-1-tetralol (10)}

Melting point: $91.6-97.0{ }^{\circ} \mathrm{C}$; purity: $99.5 \%$; yield (final step): $30.4 \% .{ }^{1} \mathrm{H}$ NMR $\left(600 \mathrm{MHz}, \mathrm{CDCl}_{3}\right) \delta 7.30-7.25(\mathrm{~m}$, $5 \mathrm{H}), 6.74(\mathrm{dd}, J=8.5,2.7 \mathrm{~Hz}, 1 \mathrm{H}), 6.61(\mathrm{~d}, J=2.5 \mathrm{~Hz}, 1 \mathrm{H})$, $4.93(\mathrm{~s}, 2 \mathrm{H}), 4.70-4.64(\mathrm{~m}, 1 \mathrm{H}), 2.71(\mathrm{dt}, J=17.2,5.3 \mathrm{~Hz}$, $1 \mathrm{H}), 2.65-2.57(\mathrm{~m}, 1 \mathrm{H}), 1.91-1.85(\mathrm{~m}, 1 \mathrm{H}), 1.88-1.79$ $(\mathrm{m}, 1 \mathrm{H}), 1.73-1.64(\mathrm{~m}, 1 \mathrm{H}), 1.57(\mathrm{~d}, J=5.7 \mathrm{~Hz}, 1 \mathrm{H}) .{ }^{13} \mathrm{C}$ $\operatorname{NMR}\left(151 \mathrm{MHz}, \mathrm{CDCl}_{3}\right) \delta 157.82,138.74,135.58,133.70$, $131.75,130.14,128.75,128.71,114.45,113.21,69.15$, 67.64, 32.39, 29.61, 18.58. APCI-HRMS $m / z$ : calculated for $\mathrm{C}_{17} \mathrm{H}_{17} \mathrm{ClO}_{2}\left(\mathrm{M}^{+}\right)$, 288.0917, found 288.0925.

\section{7-(4-Chlorobenzyloxy)-1-tetralol (1p)}

Melting point: $95.4-98.2{ }^{\circ} \mathrm{C}$; purity: $99.6 \%$; yield (final step): $54.7 \% .{ }^{1} \mathrm{H}$ NMR (600 MHz, chloroform- $d$ ) $\delta 7.31-7.24$ $(\mathrm{m}, 4 \mathrm{H}), 6.98(\mathrm{~d}, J=2.7 \mathrm{~Hz}, 1 \mathrm{H}), 6.94(\mathrm{~d}, J=8.4 \mathrm{~Hz}$, $1 \mathrm{H}), 6.74(\mathrm{dd}, J=8.4,2.8 \mathrm{~Hz}, 1 \mathrm{H}), 4.94(\mathrm{~d}, J=2.0 \mathrm{~Hz}$, $2 \mathrm{H}), 4.68-4.61(\mathrm{~m}, 1 \mathrm{H}), 2.67(\mathrm{dt}, J=16.5,6.0 \mathrm{~Hz}, 1 \mathrm{H})$, 2.62-2.54 (m, 1H), 1.97-1.89 (m, 1H), 1.91-1.81 (m, 1H), $1.81-1.73(\mathrm{~m}, 1 \mathrm{H}), 1.71-1.64(\mathrm{~m}, 1 \mathrm{H}) .{ }^{13} \mathrm{C}$ NMR $(151 \mathrm{MHz}$, $\left.\mathrm{CDCl}_{3}\right) \delta 156.92,139.97,135.68,133.66,130.03,129.66$, 128.76, 128.73, 115.05, 113.77, 69.27, 68.48, 32.44, 28.46, 19.21. APCI-HRMS $m / z$ : calculated for $\mathrm{C}_{17} \mathrm{H}_{17} \mathrm{ClO}_{2}\left(\mathrm{M}^{+}\right)$, 288.0917, found 288.0938. 


\section{7-Hydroxy-4-chromanone (12)}

Melting point: 143.6-143.8\%; purity: $98.0 \%$; yield: $75.1 \%$. ${ }^{1} \mathrm{H}$ NMR $\left(600 \mathrm{MHz}, \mathrm{DMSO}-d_{6}\right) \delta 10.56(\mathrm{~s}, 1 \mathrm{H}), 7.60(\mathrm{~d}$, $J=8.7 \mathrm{~Hz}, 1 \mathrm{H}), 6.47(\mathrm{dd}, J=8.7,2.3 \mathrm{~Hz}, 1 \mathrm{H}), 6.30(\mathrm{~d}$, $J=2.3 \mathrm{~Hz}, 1 \mathrm{H}$ ), 4.42 (t, $J=6.4 \mathrm{~Hz}, 2 \mathrm{H}), 2.63$ (t, $J=6.4 \mathrm{~Hz}$, $2 \mathrm{H}) .{ }^{13} \mathrm{C}$ NMR $\left(151 \mathrm{MHz}, \mathrm{DMSO}-d_{6}\right) \delta 189.87,164.48$, $163.45,128.62,114.02,110.47,102.45,66.99,36.97$. APCIHRMS $m / z$ : calculated for $\mathrm{C}_{9} \mathrm{H}_{9} \mathrm{O}_{3}\left(\mathrm{MH}^{+}\right), 165.0546$, found 165.0552.

\section{7-Benzyloxy-4-chromanone (2a)}

Melting point: $101.2-101.4 \%$; purity: $98.8 \%$; Yield: $70.6 \%$. ${ }^{1} \mathrm{H}$ NMR $\left(600 \mathrm{MHz}, \mathrm{CDCl}_{3}\right) \delta 7.83(\mathrm{~d}, J=8.8 \mathrm{~Hz}, 1 \mathrm{H})$, $7.45-7.36(\mathrm{~m}, 4 \mathrm{H}), 7.36-7.30(\mathrm{~m}, 1 \mathrm{H}), 6.64(\mathrm{dd}, J=8.8$, $2.4 \mathrm{~Hz}, 1 \mathrm{H}), 6.47(\mathrm{~d}, J=2.4 \mathrm{~Hz}, 1 \mathrm{H}), 5.07(\mathrm{~s}, 2 \mathrm{H}), 4.49$ $(\mathrm{t}, J=6.3 \mathrm{~Hz}, 2 \mathrm{H}), 2.73(\mathrm{t}, J=6.3 \mathrm{~Hz}, 2 \mathrm{H}) .{ }^{13} \mathrm{C}$ NMR $\left(151 \mathrm{MHz}, \mathrm{CDCl}_{3}\right) \delta 190.47,165.01,163.70,135.86$, 128.92, 128.69, 128.29, 127.47, 115.44, 110.42, 101.74, $70.25,67.35,37.42$. APCI-HRMS $m / z$ : calculated for $\mathrm{C}_{16} \mathrm{H}_{15} \mathrm{O}_{3}\left(\mathrm{MH}^{+}\right)$, 255.1016, found 255.1028.

\section{7-(2-Phenylethoxy)-4-chromanone (2b)}

Melting point: $77.8-77.9 \%$; purity: $96.4 \%$; yield: $70.4 \%$. ${ }^{1} \mathrm{H}$ NMR $\left(600 \mathrm{MHz}, \mathrm{CDCl}_{3}\right) \delta 7.81(\mathrm{~d}, J=8.8 \mathrm{~Hz}, 1 \mathrm{H})$, 7.35-7.28 (m, 2H), 7.28-7.21 (m, 3H), 6.55 (dd, $J=8.8$, $2.4 \mathrm{~Hz}, 1 \mathrm{H}), 6.38(\mathrm{~d}, J=2.4 \mathrm{~Hz}, 1 \mathrm{H}), 4.49(\mathrm{t}, J=6.5 \mathrm{~Hz}$, 2H), 4.18 (t, $J=7.1 \mathrm{~Hz}, 2 \mathrm{H}), 3.09$ (t, $J=7.1 \mathrm{~Hz}, 2 \mathrm{H}), 2.73$ (t, $J=6.3 \mathrm{~Hz}, 2 \mathrm{H}) .{ }^{13} \mathrm{C}$ NMR $\left(151 \mathrm{MHz}, \mathrm{CDCl}_{3}\right) \delta 190.52$, 165.16, 163.75, 137.66, 128.94, 128.87, 128.55, 126.67, $115.26,110.21,101.31,68.97,67.34,37.41,35.47$. APCIHRMS $m / z$ : calculated for $\mathrm{C}_{17} \mathrm{H}_{17} \mathrm{O}_{3}\left(\mathrm{MH}^{+}\right), 269.1172$, found 269.1179 .

\section{7-(3-Phenylpropoxy)-4-chromanone (2c)}

Melting point: $78.5-78.6 \%$; purity: $99.5 \%$; yield: $73.1 \%$. ${ }^{1} \mathrm{H}$ NMR $\left(600 \mathrm{MHz}, \mathrm{CDCl}_{3}\right) \delta 7.81(\mathrm{~d}, J=8.8 \mathrm{~Hz}, 1 \mathrm{H})$, $7.30-7.25(\mathrm{~m}, 2 \mathrm{H}), 7.22-7.15(\mathrm{~m}, 3 \mathrm{H}), 6.56(\mathrm{dd}, J=8.8$, $2.4 \mathrm{~Hz}, 1 \mathrm{H}), 6.36(\mathrm{~d}, J=2.4 \mathrm{~Hz}, 1 \mathrm{H}), 4.49(\mathrm{t}, J=6.5 \mathrm{~Hz}$, $2 \mathrm{H}), 3.96(\mathrm{t}, J=6.3 \mathrm{~Hz}, 2 \mathrm{H}), 2.79(\mathrm{t}, J=7.7 \mathrm{~Hz}, 2 \mathrm{H}), 2.72$ $(\mathrm{t}, J=6.3 \mathrm{~Hz}, 2 \mathrm{H}), 2.15-2.05(\mathrm{~m}, 2 \mathrm{H}) .{ }^{13} \mathrm{C}$ NMR $(151 \mathrm{MHz}$, $\left.\mathrm{CDCl}_{3}\right) \delta 190.47,165.39,163.73,141.06,128.83,128.45$, 126.03, 115.17, 110.22, 101.19, 67.33, 67.23, 37.41, 31.96, 30.47. APCI-HRMS m/z: calculated for $\mathrm{C}_{18} \mathrm{H}_{19} \mathrm{O}_{3}\left(\mathrm{MH}^{+}\right)$, 283.13229, found 283.1351.

\section{7-(2-Cyclohexylethoxy)-4-chromanone (2d)}

Melting point: $88.5-88.8 \%$; purity: $97.5 \%$; yield: $73.0 \% .{ }^{1} \mathrm{H}$ NMR $\left(600 \mathrm{MHz}, \mathrm{CDCl}_{3}\right) \delta 7.80(\mathrm{~d}, J=8.8 \mathrm{~Hz}, 1 \mathrm{H}), 6.54$ (dd, $J=8.8,2.4 \mathrm{~Hz}, 1 \mathrm{H}), 6.37$ (d, $J=2.4 \mathrm{~Hz}, 1 \mathrm{H}), 4.48$ (t, $J=6.4 \mathrm{~Hz}, 2 \mathrm{H}), 4.00(\mathrm{t}, J=6.6 \mathrm{~Hz}, 2 \mathrm{H}), 2.74(\mathrm{t}, J=6.4 \mathrm{~Hz}$, $2 \mathrm{H}), 1.81-1.54(\mathrm{~m}, 6 \mathrm{H}), 1.53-1.40(\mathrm{~m}, 1 \mathrm{H}), 1.34-1.07(\mathrm{~m}$, 4H), 1.01-0.76 (m, 2H). ${ }^{13} \mathrm{C}$ NMR (151 MHz, $\left.\mathrm{CDCl}_{3}\right) \delta$ 190.56, 165.58, 163.77, 128.79, 115.03, 110.30, 101.14, 67.32, 66.43, 37.41, 36.27, 34.44, 33.21, 29.68, 26.45, 26.17. APCI-HRMS $m / z$ : calculated for $\mathrm{C}_{17} \mathrm{H}_{23} \mathrm{O}_{3}\left(\mathrm{MH}^{+}\right)$, 275.1642 , found 275.1653 .

\section{7-(4-Bromobenzyloxy)-4-chromanone (2e)}

Melting point: $144.8-144.9 \%$; purity: $97.5 \%$; yield: $68.3 \%$. ${ }^{1} \mathrm{H}$ NMR $\left(600 \mathrm{MHz}, \mathrm{CDCl}_{3}\right) \delta 7.82(\mathrm{~d}, J=8.8 \mathrm{~Hz}, 1 \mathrm{H})$, $7.50(\mathrm{~d}, J=8.3 \mathrm{~Hz}, 2 \mathrm{H}), 7.27(\mathrm{~d}, J=8.4 \mathrm{~Hz}, 2 \mathrm{H}), 6.61$ (dd, $J=8.8,2.4 \mathrm{~Hz}, 1 \mathrm{H}), 6.43(\mathrm{~d}, J=2.4 \mathrm{~Hz}, 1 \mathrm{H}), 5.02(\mathrm{~s}$, $2 \mathrm{H}), 4.49(\mathrm{t}, J=6.5 \mathrm{~Hz}, 2 \mathrm{H}), 2.73(\mathrm{t}, J=6.5 \mathrm{~Hz}, 2 \mathrm{H}) .{ }^{13} \mathrm{C}$ NMR $\left(151 \mathrm{MHz}, \mathrm{CDCl}_{3}\right) \delta 190.42,164.64,163.66,134.89$, 131.83, 129.02, 128.98, 122.23, 115.58, 110.31, 101.75, $69.43,67.36,37.39$. APCI-HRMS $m / z$ : calculated for $\mathrm{C}_{16} \mathrm{H}_{14} \mathrm{BrO}_{3}\left(\mathrm{MH}^{+}\right), 333.0121$, found 333.0089.

\section{7-(4-Chlorobenzyloxy)-4-chromanone (2f)}

Melting point: $121.3-121.5 \%$; purity: $99.5 \%$; yield: $69.6 \%$. ${ }^{1} \mathrm{H}$ NMR $\left(600 \mathrm{MHz}, \mathrm{CDCl}_{3}\right) \delta 7.83(\mathrm{~d}, J=8.8 \mathrm{~Hz}, 1 \mathrm{H})$, 7.39-7.30 (m, 4H), $6.62(\mathrm{dd}, J=8.8,2.4 \mathrm{~Hz}, 1 \mathrm{H}), 6.43$ (d, $J=2.4 \mathrm{~Hz}, 1 \mathrm{H}), 5.04(\mathrm{~s}, 2 \mathrm{H}), 4.50(\mathrm{t}, J=6.4 \mathrm{~Hz}, 2 \mathrm{H}), 2.74$ (t, $J=6.4 \mathrm{~Hz}, 2 \mathrm{H}) .{ }^{13} \mathrm{C}$ NMR $\left(151 \mathrm{MHz}, \mathrm{CDCl}_{3}\right) \delta 190.43$, $164.69,163.68,134.38,134.14,129.00,128.90,128.76$, 115.59, 110.33, 101.77, 69.44, 67.38, 37.41. APCI-HRMS $\mathrm{m} / z$ : calculated for $\mathrm{C}_{16} \mathrm{H}_{14} \mathrm{ClO}_{3}\left(\mathrm{MH}^{+}\right), 289.0626$, found 289.0611 .

\section{7-(4-Methylbenzyloxy)-4-chromanone (2g)}

Melting point: $132.4-133.5 \%$; purity: $97.6 \%$; yield: $74.3 \%$. ${ }^{1} \mathrm{H}$ NMR $\left(600 \mathrm{MHz}, \mathrm{CDCl}_{3}\right) \delta 7.81(\mathrm{~d}, J=8.8 \mathrm{~Hz}, 1 \mathrm{H})$, $7.28(\mathrm{~d}, J=8.0 \mathrm{~Hz}, 2 \mathrm{H}), 7.18(\mathrm{~d}, J=7.8 \mathrm{~Hz}, 2 \mathrm{H}), 6.62(\mathrm{dd}$, $J=8.8,2.4 \mathrm{~Hz}, 1 \mathrm{H}), 6.46(\mathrm{~d}, J=2.4 \mathrm{~Hz}, 1 \mathrm{H}), 5.02(\mathrm{~s}, 2 \mathrm{H})$, 4.49 (t, $J=6.3 \mathrm{~Hz}, 2 \mathrm{H}), 2.73(\mathrm{t}, J=6.2 \mathrm{~Hz}, 2 \mathrm{H}), 2.34$ (s, 3H). ${ }^{13} \mathrm{C}$ NMR $\left(151 \mathrm{MHz}, \mathrm{CDCl}_{3}\right) \delta 190.69,165.16,163.74$, 138.17, 132.77, 129.37, 128.89, 127.63, 115.30, 110.49, $101.70,70.23,67.31,37.37,21.20$. APCI-HRMS $m / z$ : calculated for $\mathrm{C}_{17} \mathrm{H}_{17} \mathrm{O}_{3}\left(\mathrm{MH}^{+}\right)$, 269.1172, found 269.1176.

\section{7-(4-Fluorobenzyloxy)-4-chromanone (2h)}

Melting point: $92.8-94.6 \%$; purity: $99.4 \%$; yield: $75.3 \%$. ${ }^{1} \mathrm{H} \mathrm{NMR}\left(600 \mathrm{MHz}, \mathrm{CDCl}_{3}\right) \delta 7.83(\mathrm{~d}, J=8.8 \mathrm{~Hz}, 1 \mathrm{H})$, $7.41-7.33(\mathrm{~m}, 2 \mathrm{H}), 7.06(\mathrm{t}, J=8.6 \mathrm{~Hz}, 2 \mathrm{H}), 6.62(\mathrm{dd}$, $J=8.8,2.4 \mathrm{~Hz}, 1 \mathrm{H}), 6.45(\mathrm{~d}, J=2.4 \mathrm{~Hz}, 1 \mathrm{H}), 5.02(\mathrm{~s}, 2 \mathrm{H})$, $4.49(\mathrm{t}, J=6.4 \mathrm{~Hz}, 2 \mathrm{H}), 2.73(\mathrm{t}, J=6.2 \mathrm{~Hz}, 2 \mathrm{H}) .{ }^{13} \mathrm{C} \mathrm{NMR}$ $\left(151 \mathrm{MHz}, \mathrm{CDCl}_{3}\right) \delta 190.45,164.77,163.68,163.43$, 
$161.80,131.62,131.60,129.40,129.35,128.96,115.71$, $115.57,115.51,110.33,101.70,69.55,67.36,37.39$. APCIHRMS $m / z$ : calculated for $\mathrm{C}_{16} \mathrm{H}_{14} \mathrm{FO}_{3}\left(\mathrm{MH}^{+}\right), 273.0921$, found 273.0918 .

\section{7-[(4-Trifluoromethyl)benzyloxy]-4-chromanone (2i)}

Melting point: $129.7-130.3 \%$; purity: $99.5 \%$; yield: $66.7 \%$. ${ }^{1} \mathrm{H}$ NMR $\left(600 \mathrm{MHz}, \mathrm{CDCl}_{3}\right) \delta 7.84(\mathrm{~d}, J=8.8 \mathrm{~Hz}, 1 \mathrm{H})$, $7.64(\mathrm{~d}, J=8.1 \mathrm{~Hz}, 2 \mathrm{H}), 7.52(\mathrm{~d}, J=7.9 \mathrm{~Hz}, 2 \mathrm{H}), 6.63$ $(\mathrm{dd}, J=8.8,2.4 \mathrm{~Hz}, 1 \mathrm{H}), 6.44(\mathrm{~d}, J=2.4 \mathrm{~Hz}, 1 \mathrm{H}), 5.13(\mathrm{~s}$, $2 \mathrm{H}), 4.49(\mathrm{t}, J=6.4 \mathrm{~Hz}, 2 \mathrm{H}), 2.74(\mathrm{t}, J=6.4 \mathrm{~Hz}, 2 \mathrm{H}) .{ }^{13} \mathrm{C}$ NMR $\left(151 \mathrm{MHz}, \mathrm{CDCl}_{3}\right) \delta 190.42,164.50,163.69,139.93$, $130.54,130.32$, 129.08, 127.36, 125.71, 125.68, 125.65, $125.63,123.05,115.71,110.25,101.80,69.28,67.39$, 37.40. APCI-HRMS $m / z$ : calculated for $\mathrm{C}_{17} \mathrm{H}_{14} \mathrm{~F}_{3} \mathrm{O}_{3}\left(\mathrm{MH}^{+}\right)$, 323.0890 , found 323.0895 .

\section{7-(2-Phenoxyethoxy)-4-chromanone (2j)}

Melting point: $125.0-125.2 \%$; purity: $99.5 \%$; yield: $71.0 \%$. ${ }^{1} \mathrm{H} \mathrm{NMR}\left(600 \mathrm{MHz}, \mathrm{CDCl}_{3}\right) \delta 7.83(\mathrm{~d}, J=8.8 \mathrm{~Hz}, 1 \mathrm{H})$, $7.32-7.25(\mathrm{~m}, 2 \mathrm{H}), 6.96(\mathrm{t}, J=7.4 \mathrm{~Hz}, 1 \mathrm{H}), 6.92(\mathrm{~d}$, $J=7.6 \mathrm{~Hz}, 2 \mathrm{H}), 6.61(\mathrm{dd}, J=8.8,2.4 \mathrm{~Hz}, 1 \mathrm{H}), 6.44(\mathrm{~d}$, $J=2.4 \mathrm{~Hz}, 1 \mathrm{H}), 4.50(\mathrm{t}, J=6.7 \mathrm{~Hz}, 2 \mathrm{H}), 4.37-4.26(\mathrm{~m}, 4 \mathrm{H})$, $2.74(\mathrm{t}, J=6.3 \mathrm{~Hz}, 2 \mathrm{H}) .{ }^{13} \mathrm{C} \mathrm{NMR}\left(151 \mathrm{MHz}, \mathrm{CDCl}_{3}\right) \delta$ $190.49,164.89,163.67,158.37,129.52,128.93,121.25$, $115.51,114.60,110.17,101.50,67.36,66.80,66.00$, 37.40. APCI-HRMS $m / z$ : calculated for $\mathrm{C}_{17} \mathrm{H}_{17} \mathrm{O}_{4}\left(\mathrm{MH}^{+}\right)$, 285.1121, found 285.1090 .

\section{7-[2-(4-Chlorophenoxy)ethoxy]-4-chromanone (2k)}

Melting point: 145.9-146.2\%; purity: $94.9 \%$; yield: $77.6 \%$. ${ }^{1} \mathrm{H}$ NMR $\left(600 \mathrm{MHz}, \mathrm{CDCl}_{3}\right) \delta 7.83(\mathrm{~d}, J=8.8 \mathrm{~Hz}, 1 \mathrm{H})$, 7.27-7.21 (m, 2H), 6.91-6.81 (m, 2H), 6.61 (dd, $J=8.8$, $2.4 \mathrm{~Hz}, 1 \mathrm{H}), 6.44(\mathrm{~d}, J=2.4 \mathrm{~Hz}, 1 \mathrm{H}), 4.50(\mathrm{t}, J=6.5 \mathrm{~Hz}$, $2 \mathrm{H}), 4.35-4.30(\mathrm{~m}, 2 \mathrm{H}), 4.30-4.25(\mathrm{~m}, 2 \mathrm{H}), 2.74(\mathrm{t}$, $J=6.4 \mathrm{~Hz}, 2 \mathrm{H}) .{ }^{13} \mathrm{C} \mathrm{NMR}\left(151 \mathrm{MHz}, \mathrm{CDCl}_{3}\right) \delta 190.52$, $164.78,163.69,157.02,129.40,128.99,126.17,115.92$, $115.58,110.12,101.50,67.37,66.67,66.44,37.40$. APCIHRMS $m / z$ : calculated for $\mathrm{C}_{17} \mathrm{H}_{16} \mathrm{ClO}_{4}\left(\mathrm{MH}^{+}\right), 319.0732$, found 319.0692 .

\section{7-[2-(4-Bromophenoxy)ethoxy]-4-chromanone (2I)}

Melting point: $163.3-164.1 \%$; purity: $89.2 \%$; yield: $78.2 \%$. ${ }^{1} \mathrm{H}$ NMR $\left(600 \mathrm{MHz}, \mathrm{CDCl}_{3}\right) \delta 7.83(\mathrm{~d}, J=8.8 \mathrm{~Hz}, 1 \mathrm{H})$, $7.36(\mathrm{~d}, J=9.0 \mathrm{~Hz}, 2 \mathrm{H}), 6.79(\mathrm{~d}, J=8.9 \mathrm{~Hz}, 2 \mathrm{H}), 6.60$ $(\mathrm{dd}, J=8.8,2.4 \mathrm{~Hz}, 1 \mathrm{H}), 6.43(\mathrm{~d}, J=2.4 \mathrm{~Hz}, 1 \mathrm{H}), 4.50(\mathrm{t}$, $J=6.5 \mathrm{~Hz}, 2 \mathrm{H}), 4.34-4.29$ (m, 2H), 4.29-4.25 (m, 2H), 2.74 (t, $J=6.5 \mathrm{~Hz}, 2 \mathrm{H}) .{ }^{13} \mathrm{C}$ NMR $\left(151 \mathrm{MHz}, \mathrm{CDCl}_{3}\right) \delta 190.48$, $164.75,163.67,157.52,132.32,128.97,116.42,115.57$,
113.46, 110.10, 101.49, 67.36, 66.64, 66.36, 37.39. APCIHRMS $m / z$ : calculated for $\mathrm{C}_{17} \mathrm{H}_{16} \mathrm{BrO}_{4}\left(\mathrm{MH}^{+}\right), 363.0226$, found 363.0191 .

\section{7-[2-(4-Methoxyphenyl)ethoxy]-4-chromanone (2m)}

Melting point: $87.5-88.4 \%$; purity: $96.1 \%$; yield: $78.0 \%$. ${ }^{1} \mathrm{H}$ NMR $\left(600 \mathrm{MHz}, \mathrm{CDCl}_{3}\right) \delta 7.80(\mathrm{~d}, J=8.8 \mathrm{~Hz}, 1 \mathrm{H}), 7.17(\mathrm{~d}$, $J=8.6 \mathrm{~Hz}, 2 \mathrm{H}), 6.84(\mathrm{~d}, J=8.7 \mathrm{~Hz}, 2 \mathrm{H}), 6.55(\mathrm{dd}, J=8.8$, $2.4 \mathrm{~Hz}, 1 \mathrm{H}), 6.37(\mathrm{~d}, J=2.4 \mathrm{~Hz}, 1 \mathrm{H}), 4.48(\mathrm{t}, J=6.4 \mathrm{~Hz}$, $2 \mathrm{H}), 4.13(\mathrm{t}, J=7.0 \mathrm{~Hz}, 2 \mathrm{H}), 3.78(\mathrm{~s}, 3 \mathrm{H}), 3.02(\mathrm{t}, J=7.0 \mathrm{~Hz}$, $2 \mathrm{H}), 2.73(\mathrm{t}, J=6.4 \mathrm{~Hz}, 2 \mathrm{H}) .{ }^{13} \mathrm{C}$ NMR $\left(151 \mathrm{MHz}, \mathrm{CDCl}_{3}\right)$ $\delta$ 190.50, 165.19, 163.74, 158.37, 129.92, 129.66, 128.86, 115.23, 113.96, 110.22, 101.29, 69.23, 67.34, 55.26, 37.42, 34.58. APCI-HRMS $m / z$ : calculated for $\mathrm{C}_{18} \mathrm{H}_{19} \mathrm{O}_{4}\left(\mathrm{MH}^{+}\right)$, 299.1278, found 299.1258 .

\section{7-[2-(4-Chlorophenyl)ethoxy)-4-chromanone (2n)}

Melting point: $86.5-88.3 \%$; purity: $95.7 \%$; yield: $72.1 \% .{ }^{1} \mathrm{H}$ NMR $\left(600 \mathrm{MHz}, \mathrm{CDCl}_{3}\right) \delta 7.81(\mathrm{~d}, J=8.8 \mathrm{~Hz}, 1 \mathrm{H}), 7.27$ $(\mathrm{d}, J=7.8 \mathrm{~Hz}, 2 \mathrm{H}), 7.25-7.22(\mathrm{~m}, 1 \mathrm{H}), 7.18(\mathrm{~d}, J=8.1 \mathrm{~Hz}$, $2 \mathrm{H}), 6.54(\mathrm{dd}, J=8.7,2.2 \mathrm{~Hz}, 1 \mathrm{H}), 6.36(\mathrm{~d}, J=2.3 \mathrm{~Hz}$, $1 \mathrm{H}), 4.49(\mathrm{t}, J=6.6 \mathrm{~Hz}, 2 \mathrm{H}), 4.15(\mathrm{t}, J=6.9 \mathrm{~Hz}, 2 \mathrm{H}), 3.05$ $(\mathrm{t}, J=6.7 \mathrm{~Hz}, 2 \mathrm{H}), 2.73(\mathrm{t}, J=6.7 \mathrm{~Hz}, 2 \mathrm{H})$. APCI-HRMS $m / z$ : calculated for $\mathrm{C}_{17} \mathrm{H}_{16} \mathrm{ClO}_{3}\left(\mathrm{MH}^{+}\right)$, 3.3.0782, found 303.0805 .

\section{7-[2-(4-Fluorophenoxy)ethoxy]-4-chromanone (20)}

Melting point: $114.9-115.2 \%$; purity: $96.6 \%$; yield: $75.1 \%$. ${ }^{1} \mathrm{H}$ NMR $\left(600 \mathrm{MHz}, \mathrm{CDCl}_{3}\right) \delta 7.83(\mathrm{~d}, J=8.8 \mathrm{~Hz}, 1 \mathrm{H})$, $7.02-6.93(\mathrm{~m}, 2 \mathrm{H}), 6.90-6.82(\mathrm{~m}, 2 \mathrm{H}), 6.61(\mathrm{dd}, J=8.8$, $2.4 \mathrm{~Hz}, 1 \mathrm{H}), 6.44(\mathrm{~d}, J=2.4 \mathrm{~Hz}, 1 \mathrm{H}), 4.50(\mathrm{t}, J=6.4 \mathrm{~Hz}, 2 \mathrm{H})$, 4.37-4.29 (m, 2H), 4.29-4.22 (m, 2H), 2.74 (t, $J=6.4 \mathrm{~Hz}$, 2H). ${ }^{13} \mathrm{C}$ NMR $\left(151 \mathrm{MHz}, \mathrm{CDCl}_{3}\right) \delta 190.49,164.84,163.69$, 154.54, 128.99, 115.98, 115.83, 115.78, 115.73, 115.57, 110.15, 101.51, 67.38, 66.85, 66.79, 37.42. APCI-HRMS $m / z$ : calculated for $\mathrm{C}_{17} \mathrm{H}_{16} \mathrm{FO}_{4}\left(\mathrm{MH}^{+}\right)$, 303.1027, found 303.1003 .

\section{7-[2-(4-Methylphenyl)ethoxy]-4-chromanone (2p)}

Melting point: $87.9-88.8 \%$; purity: $96.4 \%$; yield: $66.3 \%$. ${ }^{1} \mathrm{H}$ $\operatorname{NMR}\left(600 \mathrm{MHz}, \mathrm{CDCl}_{3}\right) \delta 7.80(\mathrm{~d}, J=8.8 \mathrm{~Hz}, 1 \mathrm{H}), 7.14(\mathrm{~d}$, $J=8.1 \mathrm{~Hz}, 2 \mathrm{H}), 7.11(\mathrm{~d}, J=7.9 \mathrm{~Hz}, 2 \mathrm{H}), 6.55(\mathrm{dd}, J=8.8$, $2.4 \mathrm{~Hz}, 1 \mathrm{H}), 6.37(\mathrm{~d}, J=2.4 \mathrm{~Hz}, 1 \mathrm{H}), 4.48(\mathrm{t}, J=6.4 \mathrm{~Hz}$, $2 \mathrm{H}), 4.15(\mathrm{t}, J=7.2 \mathrm{~Hz}, 2 \mathrm{H}), 3.04(\mathrm{t}, J=7.0 \mathrm{~Hz}, 2 \mathrm{H}), 2.73(\mathrm{t}$, $J=6.3 \mathrm{~Hz}, 2 \mathrm{H}), 2.31(\mathrm{~s}, 3 \mathrm{H}) \cdot{ }^{13} \mathrm{C}$ NMR $\left(151 \mathrm{MHz}, \mathrm{CDCl}_{3}\right)$ $\delta 190.53,165.20,163.74,136.24,134.51,129.23,128.85$, $128.82,115.22,110.23,101.28,69.12,67.33,37.41,35.01$, 21.03. APCI-HRMS $m / z$ : calculated for $\mathrm{C}_{18} \mathrm{H}_{19} \mathrm{O}_{3}\left(\mathrm{MH}^{+}\right)$, 283.1329 , found 283.1330 . 


\section{7-Isoamyloxy-4-chromanone (2q)}

Melting point: $80.5-81.9 \%$; purity: $99.5 \%$; yield: $64.4 \%$. ${ }^{1} \mathrm{H}$ NMR $\left(600 \mathrm{MHz}, \mathrm{CDCl}_{3}\right) \delta 7.80(\mathrm{~d}, J=8.9 \mathrm{~Hz}, 1 \mathrm{H})$, $6.54(\mathrm{dd}, J=8.9,2.4 \mathrm{~Hz}, 1 \mathrm{H}), 6.37(\mathrm{~d}, J=2.4 \mathrm{~Hz}, 1 \mathrm{H})$, 4.49 (t, $J=6.3 \mathrm{~Hz}, 2 \mathrm{H}), 3.99(\mathrm{t}, J=6.6 \mathrm{~Hz}, 2 \mathrm{H}), 2.73(\mathrm{t}$, $J=6.4 \mathrm{~Hz}, 2 \mathrm{H}), 1.85-1.75(\mathrm{~m}, 1 \mathrm{H}), 1.70-1.63(\mathrm{~m}, 2 \mathrm{H})$, $0.94(\mathrm{~d}, J=6.5 \mathrm{~Hz}, 6 \mathrm{H}) .{ }^{13} \mathrm{C}$ NMR $\left(151 \mathrm{MHz}, \mathrm{CDCl}_{3}\right) \delta$ 190.49, 165.54, 163.75, 128.79, 115.06, 110.27, 101.12, $67.33,66.81,37.61,37.42,24.97,22.50$. APCI-HRMS $m / z$ : calculated for $\mathrm{C}_{14} \mathrm{H}_{19} \mathrm{O}_{3}\left(\mathrm{MH}^{+}\right)$, 235.1350, found 235.1329.

\section{$\mathrm{IC}_{50}$ determinations}

$\mathrm{IC}_{50}$ values for the inhibition of the MAOs were determined using the method reported in the literature [22, 23]. Recombinant human MAO-A and MAO-B served as enzyme sources, and all reactions were carried out in potas-

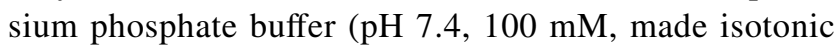
with $\mathrm{KCl})$. The reactions contained kynuramine $(50 \mu \mathrm{M})$, MAO-A (0.0075 mg protein $/ \mathrm{mL})$ or MAO-B $(0.015 \mathrm{mg}$ protein $/ \mathrm{mL})$ and the test inhibitor $(0.0003-100 \mu \mathrm{M})$ and were prepared to a final volume of $200 \mu \mathrm{L}$. Dimethyl sulfoxide (DMSO) was used to prepare stock solutions of the test inhibitors, which were added to the reactions to yield a DMSO concentration of $4 \%$. The reactions were initiated with the addition of the MAO the enzymes, incubated at $37^{\circ} \mathrm{C}$ for $20 \mathrm{~min}$ and subsequently terminated with the addition $\mathrm{NaOH}(2 \mathrm{~N}, 80 \mu \mathrm{L})$. At endpoint, the MAO-generated 4-hyroxyquinoline was measured by fluorescence spectrophotometry $\left(\lambda_{\mathrm{ex}}=310 \mathrm{~nm} ; \lambda_{\mathrm{em}}=400 \mathrm{~nm}\right)$ and quantitated with a linear calibration curve constructed with authentic 4-hydroxyquinoline $(0.047-1.56 \mu \mathrm{M})$. The rates of MAO catalysis were calculated, and the rate data were fitted to the one-site competition model incorporated into the Prism 5 software package (GraphPad). From the resulting sigmoidal plots of enzyme catalytic rate versus the logarithm of inhibitor concentration, $\mathrm{IC}_{50}$ values were determined. The $\mathrm{IC}_{50}$ values were measured in triplicate and are given as the mean \pm standard deviation $(\mathrm{SD})$.

\section{Reversibility of inhibition by dialysis}

The reversibility of inhibition was determined by dialysis according to the method reported in the literature [23]. SlideA-Lyzer dialysis cassettes (Thermo Fisher Scientific) with a molecular cutoff of 10,000 and a $0.5-3 \mathrm{~mL}$ sample volume capacity were used for dialysis, and potassium phosphate buffer (100 mM, pH 7.4) containing $5 \%$ sucrose served as dialysis buffer. The test inhibitor, at a concentration equal to $4 \times \mathrm{IC}_{50}$, and MAO $(0.03 \mathrm{mg}$ protein $/ \mathrm{mL})$ were dissolved in the dialysis buffer $(0.8 \mathrm{~mL})$, preincubated at $37{ }^{\circ} \mathrm{C}$ for $15 \mathrm{~min}$ and subsequently dialysed in $80 \mathrm{~mL}$ dialysis buffer at $4{ }^{\circ} \mathrm{C}$ for $24 \mathrm{~h}$. Stock solutions of the inhibitors were prepared in DMSO and added to the dialysis samples to yield a final concentration of $4 \%$ DMSO. The dialysis buffer was replaced at $3 \mathrm{~h}$ and $7 \mathrm{~h}$ after the start of dialysis. As positive controls, dialysis of MAO-A and MAO-B was carried out in the presence of the irreversible inhibitors, pargyline $\left(\mathrm{IC}_{50}=13 \mu \mathrm{M}\right)$ and $(\mathrm{R})$-deprenyl $\left(\mathrm{IC}_{50}=0.079 \mu \mathrm{M}\right)$, respectively $[18,32]$. As negative control, dialysis was carried out in the absence of inhibitor. After dialysis, the samples (250 $\mu \mathrm{L}$ ) were diluted twofold with the addition of kynuramine $(250 \mu \mathrm{L})$ and incubated at $37^{\circ} \mathrm{C}$ for $20 \mathrm{~min}$. This gave a final kynuramine concentration of $50 \mu \mathrm{M}$ and an inhibitor concentration of $2 \times \mathrm{IC}_{50}$. The reactions were terminated with the addition of $\mathrm{NaOH}(2 \mathrm{~N}, 400 \mu \mathrm{L})$ and water $(1000 \mu \mathrm{L})$, and 4-hydroxyquinoline was determined as described for the $\mathrm{IC}_{50}$ measurements. For comparison, undialysed samples containing the MAO enzyme and test inhibitors were maintained at $4{ }^{\circ} \mathrm{C}$ for $24 \mathrm{~h}$ and diluted and assayed as described above. All the dialysis reactions were carried out in triplicate, and the residual enzyme activities are given as the mean $\pm \mathrm{SD}$.

\section{Lineweaver-Burk plots}

For each test inhibitor, six Lineweaver-Burk plots were constructed in the absence of inhibitor and presence of five different inhibitor concentrations $\left(1 / 4 \times \mathrm{IC}_{50}, 1 / 2 \times \mathrm{IC}_{50}\right.$, $3 / 4 \times \mathrm{IC}_{50}, 1 \times \mathrm{IC}_{50}$ and $\left.1 \frac{1}{4} \times \mathrm{IC}_{50}\right)$. Eight different concentrations of kynuramine $(15-250 \mu \mathrm{M})$ were used for each plot, while the concentration of MAO was $0.015 \mathrm{mg}$ protein $/ \mathrm{mL}$. The concentration of 4-hydroxyquinoline was measured as described above for the $\mathrm{IC}_{50}$ measurements with the exception that the reactions were carried out to a volume of 500 $\mu \mathrm{L}$ and were terminated with the addition of $\mathrm{NaOH}(2 \mathrm{~N}$, $400 \mu \mathrm{L})$ and water $(1000 \mu \mathrm{L})$.

\section{Electronic supplementary material}

${ }^{1} \mathrm{H}$ NMR and ${ }^{13} \mathrm{C}$ NMR spectra for the synthesised compounds.

Acknowledgements The NMR and MS spectra were recorded by André Joubert and Johan Jordaan of the Laboratory for Analytical Services (LAS) in the focus area Chemical Resource Beneficiation, while HPLC analysis was carried out by Jan du Preez of the Analytical Technology Laboratory (ATL) at the North-West University (NWU).

Funding The financial assistance of the National Research Foundation (NRF) of South Africa [Grant specific unique Reference Numbers (UID) 85642, 96180] and NRF Innovation Fellowship (85189) towards this research is hereby acknowledged. The grant holders acknowledge that opinions, findings and conclusions or recommendations expressed in any publication generated by the NRF-supported research are those of the authors and that the NRF accepts no liability whatsoever in this regard. 


\section{Compliance with ethical standards}

Conflict of interest The authors declare that they have no conflict of interest.

\section{References}

1. Youdim MB, Bakhle YS (2006) Monoamine oxidase: isoforms and inhibitors in Parkinson's disease and depressive illness. Br J Pharmacol 147(Suppl 1):S287-S296. https://doi.org/10.1038/ sj.bjp.0706464

2. Shih JC, Chen K, Ridd MJ (1999) Monoamine oxidase: from genes to behavior. Annu Rev Neurosci 22:197-217. https://doi. org/10.1146/annurev.neuro.22.1.197

3. Shih JC (2018) Monoamine oxidase isoenzymes: genes, functions and targets for behavior and cancer therapy. J Neural Transm (Vienna) 125:1553-1566. https://doi.org/10.1007/s0070 2-018-1927-8

4. Youdim MB, Edmondson D, Tipton KF (2006) The therapeutic potential of monoamine oxidase inhibitors. Nat Rev Neurosci 7:295-309. https://doi.org/10.1038/nrn1883

5. Naoi M, Maruyama W, Shamoto-Nagai M (2018) Type A monoamine oxidase and serotonin are coordinately involved in depressive disorders: from neurotransmitter imbalance to impaired neurogenesis. J Neural Transm (Vienna) 125:53-66. https://doi. org/10.1007/s00702-017-1709-8

6. Muller T (2020) Pharmacokinetics and pharmacodynamics of levodopa/carbidopa cotherapies for Parkinson's disease. Expert Opin Drug Metab Toxicol. https://doi.org/10.1080/17425 255.2020.1750596

7. Edmondson DE (2014) Hydrogen peroxide produced by mitochondrial monoamine oxidase catalysis: biological implications. Curr Pharm Des 20:155-160. https://doi.org/10.2174/1381612811 3190990406

8. Mialet-Perez J, Santin Y, Parini A (2018) Monoamine oxidase-A, serotonin and norepinephrine: synergistic players in cardiac physiology and pathology. J Neural Transm (Vienna) 125:1627-1634. https://doi.org/10.1007/s00702-018-1908-y

9. Kaludercic N, Mialet-Perez J, Paolocci N, Parini A, Di Lisa F (2014) Monoamine oxidases as sources of oxidants in the heart. J Mol Cell Cardiol 73:34-42. https://doi.org/10.1016/j.yjmcc 2013.12.032

10. Gaur S, Gross ME, Liao CP, Qian B, Shih JC (2019) Effect of Monoamine oxidase A (MAOA) inhibitors on androgen-sensitive and castration-resistant prostate cancer cells. Prostate 79:667-677. https://doi.org/10.1002/pros.23774

11. Deshwal S, Di Sante M, Di Lisa F, Kaludercic N (2017) Emerging role of monoamine oxidase as a therapeutic target for cardiovascular disease. Curr Opin Pharmacol 33:64-69. https://doi. org/10.1016/j.coph.2017.04.003

12. Carradori S, Secci D, Petzer JP (2018) MAO inhibitors and their wider applications: a patent review. Expert Opin Ther Pat 28:211226. https://doi.org/10.1080/13543776.2018.1427735

13. Lieb J (1983) Remission of rheumatoid arthritis and other disorders of immunity in patients taking monoamine oxidase inhibitors. Int J Immunopharmacol 5:353-357. https://doi.org/10.1016/01920561(83)90039-5

14. Kast RE (1998) Crohn's disease remission with phenelzine treatment. Gastroenterology 115:1034-1035. https://doi.org/10.1016/ s0016-5085(98)70292-6

15. Legoabe LJ, Petzer A, Petzer JP (2014) alpha-Tetralone derivatives as inhibitors of monoamine oxidase. Bioorg Med Chem Lett 24:2758-2763. https://doi.org/10.1016/j.bmcl.2014.04.021
16. Legoabe LJ, Petzer A, Petzer JP (2015) The synthesis and evaluation of C7-substituted alpha-tetralone derivatives as inhibitors of monoamine oxidase. Chem Biol Drug Des 86:895-904. https ://doi.org/10.1111/cbdd.12508

17. Strydom B, Malan SF, Castagnoli N Jr, Bergh JJ, Petzer JP (2010) Inhibition of monoamine oxidase by 8-benzyloxycaffeine analogues. Bioorg Med Chem 18:1018-1028. https://doi. org/10.1016/j.bmc.2009.12.064

18. Strydom B, Bergh JJ, Petzer JP (2012) The inhibition of monoamine oxidase by 8-(2-phenoxyethoxy)caffeine analogues. Arzneimittelforschung 62:513-518. https://doi. org/10.1055/s-0032-1323662

19. Lan J-S, Xie S-S, Huang M, Hu Y-J, Kong L-Y, Wang X-B (2015) Chromanones: selective and reversible monoamine oxidase B inhibitors with nanomolar potency. MedChemComm 6:1293-1302. https://doi.org/10.1039/C5MD00124B

20. Aditya A, Nichols DE, Loudon GM (2008) Borohydride reduction of estrone: demonstration of diastereoselectivity in the undergraduate organic chemistry laboratory. J Chem Educ 85:1535-1537. https://doi.org/10.1021/ed085p1535

21. Koch K, Biggers MS (1994) General preparation of 7-substituted 4-chromanones: synthesis of a potent aldose reductase inhibitor. J Org Chem 59:1216-1218. https://doi.org/10.1021/ jo00084a050

22. Novaroli L, Reist M, Favre E, Carotti A, Catto M, Carrupt PA (2005) Human recombinant monoamine oxidase B as reliable and efficient enzyme source for inhibitor screening. Bioorg Med Chem 13:6212-6217. https://doi.org/10.1016/j.bmc.2005.06.043

23. Mostert S, Petzer A, Petzer JP (2015) Indanones as high-potency reversible inhibitors of monoamine oxidase. ChemMedChem 10:862-873. https://doi.org/10.1002/cmdc.201500059

24. Weissbach H, Smith TE, Daly JW, Witkop B, Udenfriend S (1960) A rapid spectrophotometric assay of mono-amine oxidase based on the rate of disappearance of kynuramine. J Biol Chem 235:1160-1163

25. Petzer A, Pienaar A, Petzer JP (2013) The inhibition of monoamine oxidase by esomeprazole. Drug Res (Stuttg) 63:462-467. https ://doi.org/10.1055/s-0033-1345163

26. Chimenti F, Bolasco A, Manna F, Secci D, Chimenti P, Befani O, Turini P, Giovannini V, Mondovi B, Cirilli R, La Torre F (2004) Synthesis and selective inhibitory activity of 1-acetyl-3,5-diphenyl-4,5-dihydro- $(1 \mathrm{H})$-pyrazole derivatives against monoamine oxidase. J Med Chem 47:2071-2074. https://doi.org/10.1021/ jm031042b

27. Hubalek F, Binda C, Li M, Herzig Y, Sterling J, Youdim MB, Mattevi A, Edmondson DE (2004) Inactivation of purified human recombinant monoamine oxidases $\mathrm{A}$ and $\mathrm{B}$ by rasagiline and its analogues. J Med Chem 47:1760-1766. https://doi.org/10.1021/ jm0310885

28. Son SY, Ma J, Kondou Y, Yoshimura M, Yamashita E, Tsukihara T (2008) Structure of human monoamine oxidase A at 2.2-A resolution: the control of opening the entry for substrates/ inhibitors. Proc Natl Acad Sci U S A 105:5739-5744. https://doi. org/10.1073/pnas.0710626105

29. De Colibus L, Li M, Binda C, Lustig A, Edmondson DE, Mattevi A (2005) Three-dimensional structure of human monoamine oxidase A (MAO A): relation to the structures of rat MAO A and human MAO B. Proc Natl Acad Sci U S A 102:12684-12689. https://doi.org/10.1073/pnas.0505975102

30. Binda C, Newton-Vinson P, Hubalek F, Edmondson DE, Mattevi A (2002) Structure of human monoamine oxidase B, a drug target for the treatment of neurological disorders. Nat Struct Biol 9:22-26. https://doi.org/10.1038/nsb732

31. Binda C, Wang J, Pisani L, Caccia C, Carotti A, Salvati P, Edmondson DE, Mattevi A (2007) Structures of human monoamine oxidase B complexes with selective noncovalent inhibitors: 
safinamide and coumarin analogs. J Med Chem 50:5848-5852. https://doi.org/10.1021/jm070677y

32. Petzer A, Harvey BH, Wegener G, Petzer JP (2012) Azure B, a metabolite of methylene blue, is a high-potency, reversible inhibitor of monoamine oxidase. Toxicol Appl Pharmacol 258:403-409. https://doi.org/10.1016/j.taap.2011.12.005
Publisher's Note Springer Nature remains neutral with regard to jurisdictional claims in published maps and institutional affiliations.

\section{Affiliations}

\section{Stephanus J. Cloete ${ }^{1} \cdot$ Clarina I. N'Da $^{1} \cdot$ Lesetja J. Legoabe ${ }^{1}$. Anél Petzer ${ }^{1,2} \cdot$ Jacobus P. Petzer $^{1,2} \mathbb{C}^{(1)}$}

1 Centre of Excellence for Pharmaceutical Sciences, NorthWest University, Private Bag X6001, Potchefstroom 2520, South Africa
2 Pharmaceutical Chemistry, School of Pharmacy, North-West University, Private Bag X6001, Potchefstroom 2520, South Africa 